\title{
Lysosomal Acid Lipase Deficiency Controls T- and B-Regulatory Cell Homeostasis in the Lymph Nodes of Mice with Human Cancer Xenotransplants
}

\author{
Xinchun Ding, ${ }^{*}$ Ting Zhao, ${ }^{*}$ Chih-Chun Lee, ${ }^{*}$ Cong Yan, ${ }^{* \dagger}$ and Hong Du${ }^{*}$
}

From the Department of Pathology and Laboratory Medicine* and the Indiana University Simon Cancer Center, ${ }^{\dagger}$ Indiana University School of Medicine, Indianapolis, Indiana

\author{
Accepted for publication \\ October 14, 2020. \\ Address correspondence to \\ Hong Du, Ph.D., Department of \\ Pathology and Laboratory \\ Medicine, Indiana University \\ School of Medicine, $975 \mathrm{~W}$. \\ Walnut St., IB424E, Indian- \\ apolis, IN 46202; or Cong Yan, \\ Ph.D., Department of Pathology \\ and Laboratory Medicine, Indi- \\ ana University School of Med- \\ icine, 975 W. Walnut St., \\ IB424G, Indianapolis, IN \\ 46202. E-mail: hongdu@iupui. \\ edu or coyan@iupui.edu.
}

\begin{abstract}
Utilization of proper preclinical models accelerates development of immunotherapeutics and the study of the interplay between human malignant cells and immune cells. Lysosomal acid lipase (LAL) is a critical lipid hydrolase that generates free fatty acids and cholesterol. Ablation of LAL suppresses immune rejection and allows growth of human lung cancer cells in $\mathrm{lal}^{-/-}$mice. In the $\mathrm{al}^{-/-}$lymph nodes, the percentages of both T- and B-regulatory cells (Tregs and Bregs, respectively) are increased, with elevated expression of programmed death-ligand 1 and IL-10, and decreased expression of interferon- $\gamma$. Levels of enzymes in the glucose and glutamine metabolic pathways are elevated in Tregs and Bregs of the $\mathrm{lal}^{-/-}$ lymph nodes. Pharmacologic inhibitor of pyruvate dehydrogenase, which controls the transition from glycolysis to the citric acid cycle, effectively reduces Treg and Breg elevation in the lal $^{-/}$- lymph nodes. Blocking the mammalian target of rapamycin or reactivating peroxisome proliferator-activated receptor $\gamma$, an LAL downstream effector, reduces $/ a l^{-/-}$Treg and Breg elevation and PD-L1 expression in lal $^{-/-}$Tregs and Bregs, and improves human cancer cell rejection. Treatment with PD-L1 antibody also reduces Treg and Breg elevation in the $l a l^{-/-}$lymph nodes and improves human cancer cell rejection. These observations conclude that LAL-regulated lipid metabolism is essential to maintain antitumor immunity. (Am J Pathol 2021, 191: 353-367; https://doi.org/10.1016/j.ajpath.2020.10.007)
\end{abstract}

Transplantable animal models, in which the relationship and interplay between malignant cells and immune cells can be studied, play a fundamental role in the study of oncoimmunology and development of therapeutic approaches to treat human cancer. Utilization of proper preclinical models accelerates development of immunotherapies and understanding of underlying mechanisms. ${ }^{1,2}$ The host immune system determines the fate of invading cancer cells. ${ }^{3}$ In searching for appropriate immunosuppressive mouse models to study human cancer-derived xenografts, a genetic ablation mouse model $\left(\right.$ lal $\left.^{-/-}\right)$of lysosomal acid lipase (LAL) was evaluated. ${ }^{4}$ LAL is a lipid metabolic enzyme catalyzing the hydrolysis of cholesteryl esters and triglycerides in the lysosome to generate free fatty acids and cholesterol. ${ }^{5}$ The hydrolyzed products are transported to the cytoplasm for either storage or utilization in membrane biogenesis, steroid hormone synthesis, and energy production. Although $l a l^{-/-}$mice survive into adulthood, the metabolic defect of LAL deficiency leads to severe immunodeficiency, in which the lymphocyte levels are extremely low because of impaired development, maturation, and proliferation. ${ }^{6}$ The ratio of T-regulatory cells (Tregs) and myeloid-derived suppressive cells (MDSCs) is significantly increased, which suppresses T-cell function and directly stimulates tumor growth and invasion. ${ }^{6-10}$ More importantly, the compromised immunity accelerates growth and invasion of various murine tumor cells not only

\footnotetext{
Supported by NIH grants CA138759 and CA152099 (C.Y.), HL087001 (H.D.), and CA225108 (C.Y. and H.D.); Indiana University Simon Cancer Center P30 support grant P30CA082709; and the Dean's Office of Indiana University School Medicine bridge funding.

X.D. and T.Z. contributed equally to this work.

Disclosures: None declared.
} 
in syngeneic, but also allogeneic, lal ${ }^{-/-}$mice. $^{9}$ In this report, we show that immunodeficiency delays and reduces immune rejection of human cancer cells in $l a l^{-1-}$ mice. Herein, functional roles of Tregs and B-regulatory cells (Bregs) in the $\mathrm{lal}^{-/-}$lymph nodes during failure of immune rejection, as well as the abnormal expression and function of PD-L1 in $\mathrm{lal}^{-1-}$ Tregs and Bregs in association with the metabolic switch toward glycolysis and glutamine utilization are systematically evaluated. Furthermore, the functional roles of mammalian target of rapamycin (mTOR) and peroxisome proliferator-activated receptor $\gamma(\operatorname{PPAR} \gamma) \mathrm{nu}-$ clear receptor are characterized in Tregs and Bregs of the $\mathrm{lal}^{-/-}$lymph nodes during human cancer cell rejection. We conclude that Tregs and Bregs in the $l a l^{-/-}$lymph nodes play critical roles in suppression of immune rejection of human cancer growth, together with other cell types [eg, MDSCs and endothelial cells (ECs)], in lal ${ }^{-/-}$mice. Therefore, the immunodeficient $\mathrm{lal}^{-1-}$ mouse model serves as a potential preclinical model that can be used for clinical human cancer studies.

\section{Materials and Methods}

\section{Animals and Cells}

The LAL gene knockout $\left(\mathrm{lal}^{-/-}\right)$mice were generated in our laboratory ${ }^{4}$ and backcrossed to $\mathrm{FVB} / \mathrm{N}$ for 10 generations. ${ }^{11}$ Both $l a l^{-/-}$and wild-type mice used for human cancer cell characterization were of the $\mathrm{FVB} / \mathrm{N}$ genetic background. Human lung A549 cancer cells and human breast MDA-MB-231 cancer cells were purchased from ATCC (Manassas, VA). A549 and MDA-MB-231 cells were cultured in F-12K medium and in Leibovitz L-15 medium, respectively, supplemented with $10 \%$ fetal bovine serum in a $37^{\circ} \mathrm{C}$ incubator with $5 \% \mathrm{CO}_{2}$.

\section{Xenotransplantation of Human Tumor Cells in Mice}

The human lung A549 cancer cells $\left(1 \times 10^{6}\right)$ or human breast MDA-MB-231 cancer cells $\left(5 \times 10^{6}\right)$ were subcutaneously injected to the flank region in mice. The tumor growth was monitored twice a week. The tumor volume $\left(\mathrm{mm}^{3}\right)$ was estimated by measuring the maximal length and width of a tumor and calculated using the following formula: (length $\times$ width $\left.^{2}\right) / 2$.

For in vivo rapamycin treatment, wild-type or $\mathrm{lal}^{-/-}$mice were pretreated with rapamycin $(4 \mathrm{mg} / \mathrm{kg})$ or $2 \%$ ethanol solvent (final concentration) injection via the i.p. route for four times on days $1,3,5$, and 8 . On day 8,4 hours after rapamycin or solvent injection, human lung A549 cancer cells $\left(1 \times 10^{6}\right)$ were transplanted at flank sites. Ten days later (on day 18), the mice were sacrificed and the lymph nodes were harvested for flow cytometry analysis. The treatment of rapamycin was based on the preliminary assessment. For in vivo PPAR $\gamma$ ligand treatment, wild-type or $l a l^{-/-}$mice were pretreated with 9-hydroxyoctadecadienoic acid $(50 \mu \mathrm{g})$ mouse; Cayman Chemical Co, Ann Arbor, MI) or 50\% ethanol solvent injection via i.p. route on days 1,3 , and 6 , and followed by human lung A549 cancer cell $\left(1 \times 10^{6}\right)$ transplantation at flank sites. Ten days later (on day 16), the mice were sacrificed and the lymph nodes were harvested for flow cytometry analysis. For PD-L1 antibody treatment, wild-type or $\mathrm{lal}^{-/-}$mice were pretreated with rat $\operatorname{IgG}$ (catalog number BE0090; Bio X Cell, West Lebanon, NH) or anti-mouse PD-L1 antibody (20 $\mu \mathrm{g} /$ mouse; 10F.9G2; catalog number BE0101; Bio X Cell) via i.p. route three times (days 1, 5, and 8). On day 11, human lung A549 cancer cells $\left(1 \times 10^{6}\right)$ were transplanted at flank sites. Ten days later (on day 21), the mice were sacrificed and the lymph nodes were harvested for flow cytometry analysis.

\section{Isolation of Lymph Node Cells}

The brachial, axillary, and inguinal lymph nodes were harvested from the anesthetized mice and stored in phosphatebuffered saline. The lymph nodes were crushed by the frost side of two glass slides and ground gently to release lymph node cells. Collected cells were washed twice with phosphate-buffered saline and passed through a $40-\mu \mathrm{m}$ cell strainer. The cell suspension was centrifuged at $600 \times g$ for 5 minutes to collect pellets of lymph node cells.

\section{Fluorescence Tracking of Lymph Node Cells and Human} Lung A549 Cancer Cells

To measure activated T-cell attachment to A549 cancer cells, human lung A549 cancer cells were labeled by carboxyfluorescein succinimidyl ester and seeded in a 48-well plate at $2.5 \times 10^{4}$ cells/well. The next day, lymph node cells were isolated from wild-type and $l a l^{-/-}$mice at 14 days after they were injected with or without human lung A549 cancer cells $\left(1.5 \times 10^{6}\right)$ and labeled with red fluorescence (4(or 5)-(4-(chloromethyl)benzamido)-2-(1,2,2,4,8,10,10, 11-octamethyl-1,2,10,11-tetrahydropyrano[3,2-g:5,6-g'] diquinolin-13-ium-6-yl)benzoate) dye for 20 minutes at room temperature. The labeled lymph node cells were added to a monolayer of carboxyfluorescein succinimidyl ester-labeled human lung A549 cancer cells at a 2:1 ratio (lymph node cells/ A549 cells). Images were taken after 4 hours of co-culture. The inclusion ratio was determined by counting the number of red-green cells (lymph node cells attached to A549 cells) versus green cells (A549 cells) plus red-green cells. The cell count was performed in five randomly selected fields in each group, and the experiment was independently performed five times.

\section{Flow Cytometry Analysis}

Fourteen days after injection, single cells from the lymph nodes of wild-type and $\mathrm{lal}^{-1-}$ mice with or without A549 injection were prepared by grinding. For T-cell populations, cells were stained with fluorescein isothiocyanate-conjugated anti-CD4 
antibody, phosphatidylethanolamine-conjugated (or allophycocyanin [APC]-conjugated) anti-CD25 antibody, and APC eFluor 780-conjugated anti-CD8 antibody (eBioscience, San Diego, CA) at $4^{\circ} \mathrm{C}$ for 15 minutes. For B-cell populations, cells were stained with fluorescein isothiocyanate-conjugated antiIgM antibody, phosphatidylethanolamine-conjugated antiCD23 antibody, and APC eFluor 780-conjugated anti-B220 antibody (eBioscience) at $4{ }^{\circ} \mathrm{C}$ for 15 minutes. For intracellular molecule staining, cells were fixed and permeabilized using BD Cytofix/Cytoperm Fixation/Permeabilization Kit (BD Biosciences, San Jose, CA), and then incubated with florescence-conjugated antibodies [ie, APC-conjugated antimouse forkhead box P3 (T cells only), APC-conjugated antimouse IL-10, APC-conjugated anti-mouse IL-35 (R\&D Systems, Minneapolis, MN), and APC-conjugated anti-mouse Ki67 (Biolegend, San Diego, CA)] or non-florescence-conjugated antibodies against metabolic molecules, including glucose-6-phosphate dehydrogenase, lactate dehydrogenase A, pyruvate dehydrogenase (PDH), and glutamate dehydrogenase (Cell Signaling, Beverly, MA) at $4^{\circ} \mathrm{C}$ overnight. The following day, cells were stained with Alexa Fluor 647conjugated anti-rabbit IgG antibody (eBioscience) at $4{ }^{\circ} \mathrm{C}$ for 30 minutes, and then washed for flow cytometry analysis. For analysis of PD-L1 expression in the B- or T-cell population, cells were incubated with B- or T-cell surface markers, as described above, and APC-conjugated anti-PD-L1 antibody at $4{ }^{\circ} \mathrm{C}$ for 15 minutes. After phosphate-buffered saline wash, the B-cell population was ready for flow cytometry analysis. For the T-cell population, cells were further fixed, permeabilized, and incubated with Foxp3 antibody at $4{ }^{\circ} \mathrm{C}$ overnight. For lymph node cell survival studies, lymph node cells were stained with annexin- $\mathrm{V}$ and 7 -aminoactinomycin $\mathrm{D}$ for flow cytometry analyses to determine early apoptotic cells and necrotic cells. For flow cytometry analysis, $\geq 10,000$ cells were acquired and scored using an LSRII machine (BD Biosciences) and calculated on the basis of isotype control. Data were processed using the BD CellQuest Pro software version 19.f3fcb and FlowJo version 10.6.1 (BD Biosciences).

\section{Measurement of IL-10 and IFN- $\gamma$ by Enzyme-Linked Immunosorbent Assay}

Wild-type and $l a l^{-/-}$mice were pre-injected with or without human lung A549 cancer cells $\left(1.5 \times 10^{6}\right)$. Fourteen days later, lymph node cells isolated from these mice were cultured at a density of $2 \times 10^{5}$ cells per well in 96-well plates, which were precoated with anti-CD3 monoclonal antibody $(2 \mu \mathrm{g} / \mathrm{mL})$ and anti-CD28 monoclonal antibody (5 $\mu \mathrm{g} / \mathrm{mL}$ ). The cells were treated with or without human lung A549 cancer cell lysate $(20 \mu \mathrm{g} /$ well $)$ and cultured for 2 days. The human lung A549 cancer cell lysate was prepared following procedures described previously. ${ }^{12}$ The secretion of IL-10 or interferon (IFN)- $\gamma$ in the supernatant of cultured lymph node cells was measured using OptEIA enzymelinked immunosorbent assay kits, according to manufacturer's instructions (BD Bioscience).

\section{Granzyme B Expression in CD8 ${ }^{+}$Cells of Lymph Nodes}

Freshly isolated lymph node cells from wild-type and $\mathrm{lal}^{-/-}$ mice, injected with or without A549 cells (harvested at postinjection 14 days), were cultured in 96-well plates precoated with anti-CD3 monoclonal antibody and antiCD28 monoclonal antibody. The A549 cell lysate was prepared following procedures described previously. ${ }^{12}$ The lymph node cells were treated with or without A549 cell lysate $(20 \mu \mathrm{g} / \mathrm{well})$ for 2 days. Granzyme B expression in $\mathrm{CD}^{+}$cells was measured by flow cytometry.

\section{Rapamycin, 9-HODE, CPI-613, and Anti-PD-L1 Antibody Treatment for Treg and Breg Analysis}

For rapamycin (an inhibitor of mTOR) treatment, 3- to 4month-old wild-type or $\mathrm{lal}^{-1-}$ mice were injected via the i.p. route with rapamycin $(4 \mathrm{mg} / \mathrm{kg})$ or $2 \%$ ethanol solvent at days 1,3 , and 5 . At day 8 , one additional dose of rapamycin was injected 1 hour before harvesting lymph node cells for flow cytometry. The treatment of rapamycin was modified from our previous publication. ${ }^{8}$

For 9-HODE (a natural ligand of PPAR $\gamma$ ) treatment, 3- to 4-month-old wild-type or $l a l^{-/}$mice were injected via the i.p. route with $50 \mu \mathrm{g}$ 9-HODE $(1 \mathrm{mg} / \mathrm{mL}$ dissolved in ethanol; Cayman Chemical Co) or $50 \%$ ethanol solvent on days 1, 3, and 6. Mice were sacrificed, and the lymph nodes were harvested on day 8 for flow cytometry analysis. Mice injected with $50 \mu \mathrm{L}$ ethanol were used as controls.

For CPI-613 treatment, 4- to 5-month-old wild-type or $\mathrm{lal}^{-/-}$mice were injected via the i.p. route with PDH inhibitor CPI-613 $(5 \mathrm{mg} / \mathrm{kg})$ or $15 \%$ dimethyl sulfoxide solvent at days 1, 3, 5, and 8 . Mice were sacrificed, and lymph node cells were harvested on day 10 for flow cytometry.

For PD-L1 antibody treatment, 4- to 5-month-old wildtype or $l a l^{-1-}$ mice were injected via the i.p. route with rat IgG (BE; catalog number BE0090; Bio X Cell) or rat antimouse PD-L1 antibody (I0F.9G2; catalog number BE0101; Bio X Cell) at a dosage of $20 \mu \mathrm{g} /$ mouse at days 1 , 5 , and 8 . Mice were sacrificed, and lymph node cells were harvested at day 10 for flow cytometry.

\section{Histology and Immunohistochemistry Staining}

The harvested lymph nodes were fixed with $4 \%$ paraformaldehyde at $4{ }^{\circ} \mathrm{C}$ overnight. The tissues were transferred to $70 \%$ ethanol and embedded in paraffin. The tissue blocks were divided into sections (5 $\mu \mathrm{m}$ thick). Immunohistochemistry staining against mouse CD3, B220, F4/80, and Mac-3 was performed by Immunohistochemistry Core, Department of Pathology and Laboratory Medicine, Indiana University. For PD-L1 staining, the tissue slides were deparaffinized. Antigen retrieval was performed for 30 minutes by heating in citrate buffer ( $\mathrm{pH}$ 6.0). The tissue sections were incubated with rat-anti-mouse PD-L1 antibody (clone 10F.9G2; eBioscience) at $4{ }^{\circ} \mathrm{C}$ overnight. The slides were washed, followed 
by the incubation with secondary antibody and final development with 3, 3'-diaminobenzidine kit (Vector Laboratories, Burlingame, CA) for 2 minutes. The stained slides were examined under Nikon Eclipse 80i light microscope (Nikon Instruments Inc., Melville, NY). Images were taken by NIS Elements software version 3.22 (Nikon Instruments Inc.).

\section{Statistical Analysis}

All statistical analyses were performed using GraphPad Prism 8.0 software (GraphPad Software Inc., San Diego, CA) and Microsoft Excel (Microsoft Corp., Redmond, WA). The data are mean values of multiple independent experiments and are expressed as the means \pm SD. Differences between two treatment groups were compared by using two-tailed $t$-test. When more than two groups were compared, one-way analysis of variance with Tukey multiple-testing correction was used. Two-way analysis of variance was used for grouped analyses. Results were considered statistically significant when $P<0.05$.

\section{Study Approval}

The scientific protocols related to animal uses were approved by the Institutional Animal Care and Usage Committee of Indiana University School of Medicine. Protocols involving the use of biohazard materials were approved by the Institutional Biosafety Committee and followed the guideline established by NIH. Animals were housed under Institutional Animal Care and Usage Committee-approved conditions in the facility at Indiana University School of Medicine.

\section{Results}

\section{Human Cancer Cell Xenografts in $\mathrm{lal}^{-/-}$Mice}

To evaluate if xenotransplanted human cancer cells grow in the immunodeficient $\mathrm{lal}^{-/-}$mouse model across the species, human lung A549 cancer cells were subcutaneously injected in the flank sites of $\mathrm{FVB} / \mathrm{N}$ wild-type and $\mathrm{lal}^{-/}$recipient mice. The tumor was completely eradicated in wild-type mice. In comparison, the tumors in $l a l^{-1-}$ mice grew much larger, peaking at day 10 . The tumor growth curve from day 4 to day 28 is shown in Figure 1A. This reduced and delayed human tumor rejection implies compromised immune surveillance in $\mathrm{lal}^{-/-}$mice. Similar results were observed in xenotransplanted human breast MDA-MB-231 cancer cells (Supplemental Figure S1A), indicating that more than one human cancer cell line is able to grow in $\mathrm{lal}^{-/-}$mice. In this report, the human lung A549 cancer cell model is further characterized in detail.

Lymph node draining plays a critical role in cancer rejection and eradication. ${ }^{13-15}$ The lymph nodes from wildtype and $l a l^{-/-}$mice with or without lung A549 cancer cell injection are shown in Supplemental Figure S1B, in which the lung A549 cancer cell challenge resulted in bigger lymph nodes in wild-type mice than those in $l a l^{-1-}$ mice. The attacking cytotoxicity of lymph node cells to A549 cancer cells was evaluated by a co-culture experiment after fluorescence labeling. At 4 hours of incubation, activated red fluorescence-labeled lymph node cells attached and penetrated (referred to as inclusion rates) into green fluorescence-labeled lung A549 cancer cells (Figure 1B). There was no significant difference in inclusion rates between wild-type and $\mathrm{lal}^{-/-}$groups without lung A549 cancer cell pre-injection. Lung A549 cancer cell challenge in wild-type and $\mathrm{lal}^{-/-}$groups resulted in higher inclusion rates than those without A549 cancer cell challenge, with the wild-type group having a significantly higher inclusion rate than the $\mathrm{lal}^{-/-}$group does (Figure 1B). This suggests that lymph node cells from A549-injected $\mathrm{lal}^{-/-}$mice may have compromised immune activation when attacking A549 cancer cells. To assess the quality of lymph node cells, the survival rate of $l a l^{-1-}$ lymph node cells was determined by 7-aminoactinomycin D/annexin V staining and found to be statistically lower than that of wild-type lymph node cells after overnight in vitro culture, regardless of A549 injection (Figure 1C and Supplemental Figure S1C). The morphologic shape of $l a l^{-1-}$ lymph node cells was poorly differentiated compared with that of wild-type lymph node cells after stimulation by anti-CD3/anti-CD28 antibodies (Figure 1D). Immunohistochemical staining demonstrated the architecture and distribution of $\mathrm{CD}^{+} \mathrm{T}$ cells, B220 cells, and myeloid cells in lymph nodes of wild-type and $\mathrm{lal}^{-1-}$ mice. Human lung A549 cancer cell injection resulted in more intense staining of B220 $0^{+}$cells in lymph nodes of both wild-type and $l a l^{-/-}$mice than that in uninjected mice (Figure 1E). Human lung A549 cancer cell injection resulted in more intense staining of $\mathrm{CD}^{+}$cells in wild-type lymph nodes, whereas there was less intense staining in $\mathrm{lal}^{-/}$ lymph nodes than that in uninjected mice (Figure 1E). Functionally, it has been well documented that lymph node IFN- $\gamma$ promotes antitumor immunity. ${ }^{16,17}$ Secretion of IFN$\gamma$ was strongly stimulated in wild-type lymph node cells of A549-injected mice on treatment of A549 cancer cell lysate. In contrast, A549-injected $l a l^{-1-}$ lymph node cells failed to respond to the same treatment (Figure 1F). IL-10, which mediates Treg and Breg immunosuppression, was also investigated. Even without A549 injection, lal $^{-1-}$ lymph node cells secreted a higher level of IL-10 than did wildtype lymph node cells. With A549 injection, the IL-10 level in $\mathrm{lal}^{-1-}$ lymph node cells remained higher than that in wild-type lymph node cells in response to the treatment with A549 tumor lysate (Figure 1F). Secretion of tumor necrosis factor- $\alpha$ was also examined, which showed no difference between wild-type and $l a l^{-1-}$ lymph node cells regardless of treatment with the A549 cancer cell lysate (data not shown). Granzyme $\mathrm{B}$, produced by $\mathrm{CD}^{+} \mathrm{T}$ cells, is a key factor in cancer cell death. In response to tumor antigen treatment, wild-type lymph node cells from A549-injected mice showed an increase in granzyme 
A

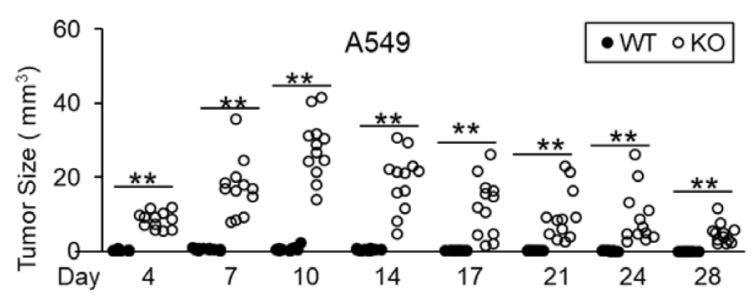

B
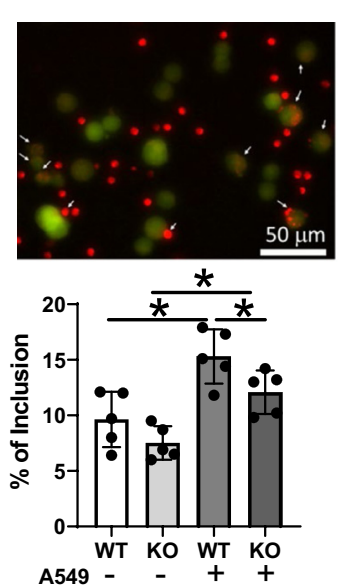

C

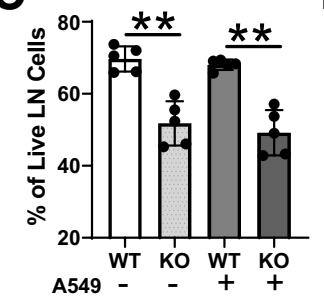

D

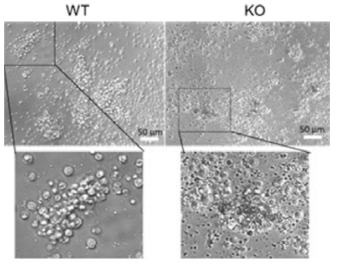

Figure 1 Growth of human cancer cells and lymph node (LN) cells in $\mathrm{lal}^{-1-}$ mice. A: The s.c. flank transplantation of human lung A549 cancer cells $\left(1 \times 10^{6}\right)$ into wild-type (WT) or lal ${ }^{-1-}$ [knockout (KO)] FVB/N mice. Tumor burden was measured by the maximal length and width of tumor: (length $x$ width $\left.{ }^{2}\right) / 2$. The experiments were independently repeated 12 times. B: The cytotoxicity of lymph node cells from WT or lal ${ }^{-1}$ (KO) mice with or without lung A549 cancer cell transplantation. The lymph node cells attaching to lung A549 cancer cells were estimated by fluorescent tracking. The CMTPX-labeled lymph node cells (red) were added to the carboxyfluorescein succinimidyl ester-labeled A549 cells (green) in a 2:1 ratio. A representative image and the statistical analysis of the inclusion rate from five repeated experiments are shown. In each experiment, five randomly selected fields under microscope are chosen for analysis. Arrows show the lymph node cells that were attached and penetrated into lung A549 cancer cells. C: The viability of lymph node cells from WT and $\mathrm{lal}^{-/-}$(KO) mice with or without lung A549 cancer cell transplantation. The lymph node cells were isolated and cultured overnight in vitro. The percentage of cell survival was determined by flow cytometry using 7-aminoactinomycin $\mathrm{D} /$ annexin $\mathrm{V}$ staining. The experiments were independently repeated five times. D: The colony morphology of WT and $\mathrm{lal}^{-1}$ (KO) lymph node cells stimulated by antiCD3/anti-CD28 antibodies for 2 days. E: Immunohistochemical staining of the $T, B$, and myeloid populations in lymph nodes from WT and $\mathrm{lal}^{-/-}$(KO) mice with or without lung A549 cancer cell transplantation. The experiments were independently repeated four times. F: Secretion of interferon (IFN) $-\gamma$ and IL-10 and intracellular expression of granzyme B (GZB) in $\mathrm{CD}^{+}$lymph node cells from WT and $\mathrm{lal}^{-1-}$ (KO) mice with or without lung A549 cancer cell transplantation after stimulation of the lung A549 cancer cell lysate for 2 days. IFN- $\gamma$ and IL-10 in the culture supernatant were determined by enzyme-linked immunosorbent assay. The experiments were independently repeated three to five times. GZB expression in $\mathrm{CD}^{+}$lymph node cells was analyzed by flow cytometry. The experiments were independently repeated five times. Data are shown as means $\pm \mathrm{SD}(\mathbf{A}, \mathbf{C}, \mathbf{F}) .{ }^{*} P<0.05$, ${ }^{* \star} P<0.01$. Scale bars: $50 \mu \mathrm{m}$ (B and D); $200 \mu \mathrm{m}$ (E). Original magnification, $\times 40$ (D, top panels); $\times 200$ (D, bottom panels); $\times 100(\mathrm{E})$.

B-positive cells compared with those from uninjected mice, but not in those of $l a l^{-/-}$lymph node cells (Supplemental Figure S1D). Taken together, LAL deficiency significantly affects morphologic formation and function of lymph node cells in response to injection of human lung A549 cancer cells.
Comparison of Lymphocyte Populations in the Wild-Type and lal $^{-/-}$Lymph Nodes

To further analyze various lymphocyte populations in the wild-type and $l a l^{-/}$lymph nodes, flow cytometry analyses were performed and compared. The total number of lymph 
A

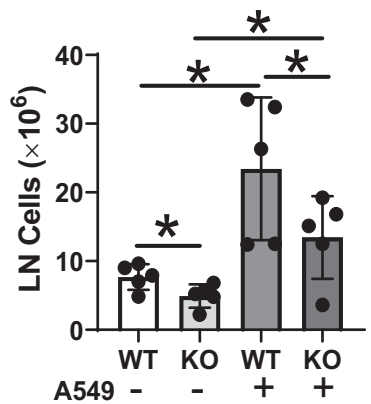

C

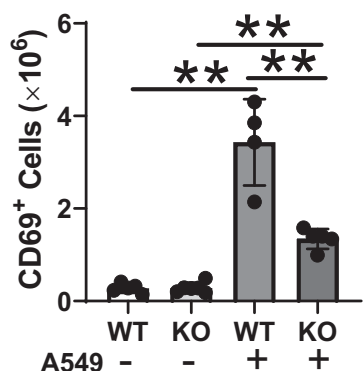

B
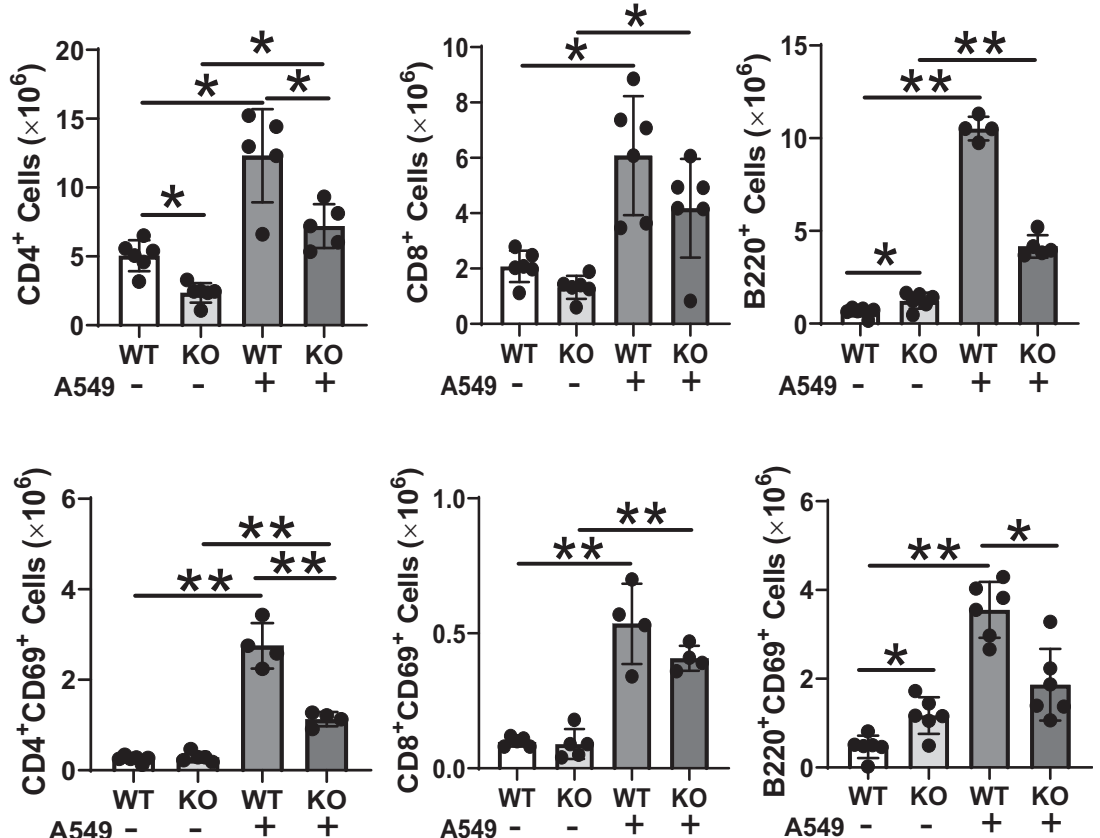

D

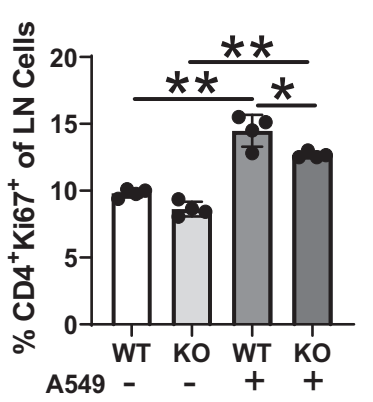

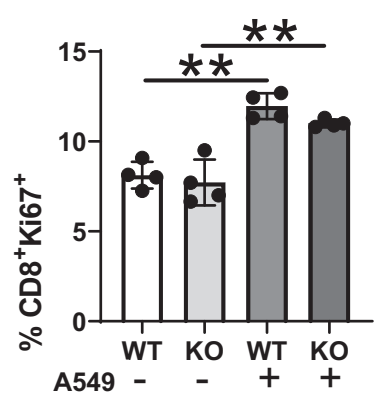

E
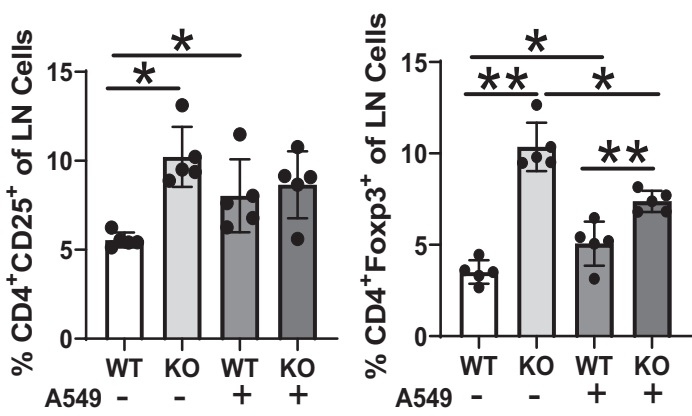

Figure 2 Lymphocyte populations in the wild-type (WT) and lal ${ }^{-/-}$lymph nodes (LNs). Lymph node cells were isolated from wild-type and lal ${ }^{-/-}$mice with or without lung A549 cancer cell transplantation and analyzed by flow cytometry using antibodies against cell surface markers. A: The total numbers of lymph node cells. B: The total numbers of $\mathrm{CD}^{+}, \mathrm{CD}^{+}$, and B220 lymphocytes. C: The total numbers of activated $\left(\mathrm{CD}^{+} 9^{+}\right) \mathrm{CD}^{+}, \mathrm{CD}^{+}$, and B220 $0^{+}$lymphocytes. D: The percentages of proliferated $\left(\mathrm{Ki}-67^{+}\right) \mathrm{CD}^{+}$and $\mathrm{CD} 8^{+}$lymphocytes. E: The percentages of $\mathrm{CD}^{+}{ }^{+} \mathrm{CD} 25^{+}$and $\mathrm{CD} 4^{+} \mathrm{FOXP3} 3^{+} \mathrm{T}_{\text {-regulatory cells. The gating }}$ strategies for B, C, D, and E are shown in Supplementary Figure S2A, S2B, S2C, and S2D, respectively. The experiments were independently repeated four to six times. Data are presented as means \pm SD $(\mathbf{A}-\mathbf{E}) .{ }^{*} P<0.05,{ }^{*} P<0.01$. K0, knockout.

node cells of $l a l^{-/-}$mice was less than that of wild-type mice (Figure 2A), which was consistent with their poor survival rate in vitro (Figure 1C). On A549 injection, the total number of lymph node cells increased significantly in both wild-type and $\mathrm{lal}^{-1-}$ mice, although to a lesser degree in $l a l^{-1-}$ mice (Figure 2A). The size of lymph nodes correlated with total number of lymph node cells (Supplemental Figure S1B). In the lymphocyte family, the total number and percentage of $\mathrm{CD}^{+}{ }^{+} \mathrm{T}$ cells were lower, and the total number and percentage of B $220^{+}$cells were higher, in the $l a l^{-1-}$ lymph node than those in the wild-type lymph node. The total number and percentage of $\mathrm{CD}^{+} \mathrm{T}$ cells showed no statistical difference (Figure 2B and Supplemental Figure S2A). With A549 injection, the total number of $\mathrm{CD} 4^{+}, \mathrm{CD} 8^{+}$, and $\mathrm{B} 220^{+}$cells all increased significantly in the wild-type and $\mathrm{lal}^{-/-}$lymph nodes compared with uninjected control groups (Figure 2B). In terms of the percentages, only B $220^{+}$cells increased in the wild-type lymph nodes in response to A549 injection (Supplemental Figure S2A). Activated lymphocytes were further measured by the lymphocyte activation marker CD69. Total activated $\mathrm{CD} 69^{+}$cells were increased in the wild-type lymph nodes after A549 injection, whereas the $\mathrm{lal}^{-1-}$ lymph nodes showed much less activation (Figure 2C). In B and $\mathrm{T}$ cells measured individually after A549 injection, total numbers and percentages of activated $\left(\mathrm{CD} 69^{+}\right) \mathrm{CD} 4^{+}$, $\mathrm{CD}^{+}$, and $\mathrm{B} 220^{+}$cells were increased in the wild-type lymph nodes (Figure 2C and Supplemental Figure S2B). In comparison, there was much less increase of the total number 
A

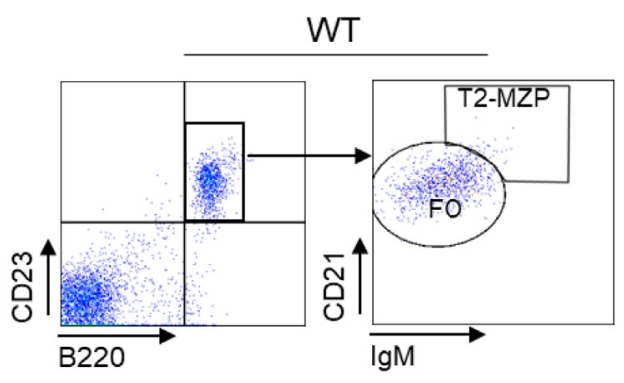

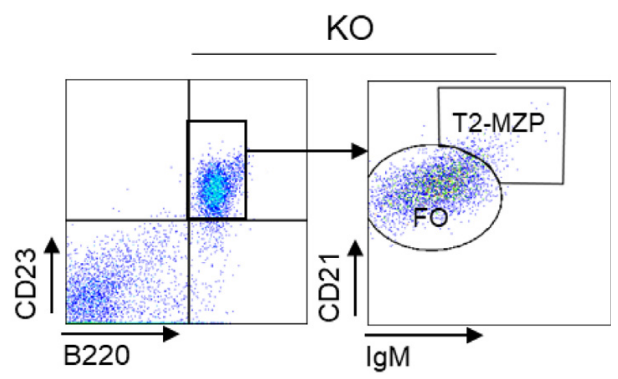

B
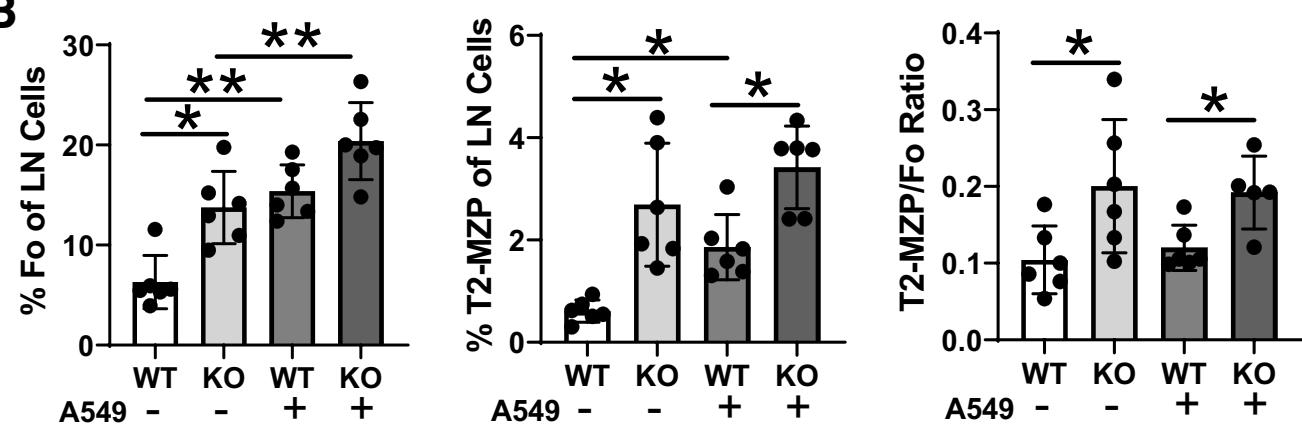

C
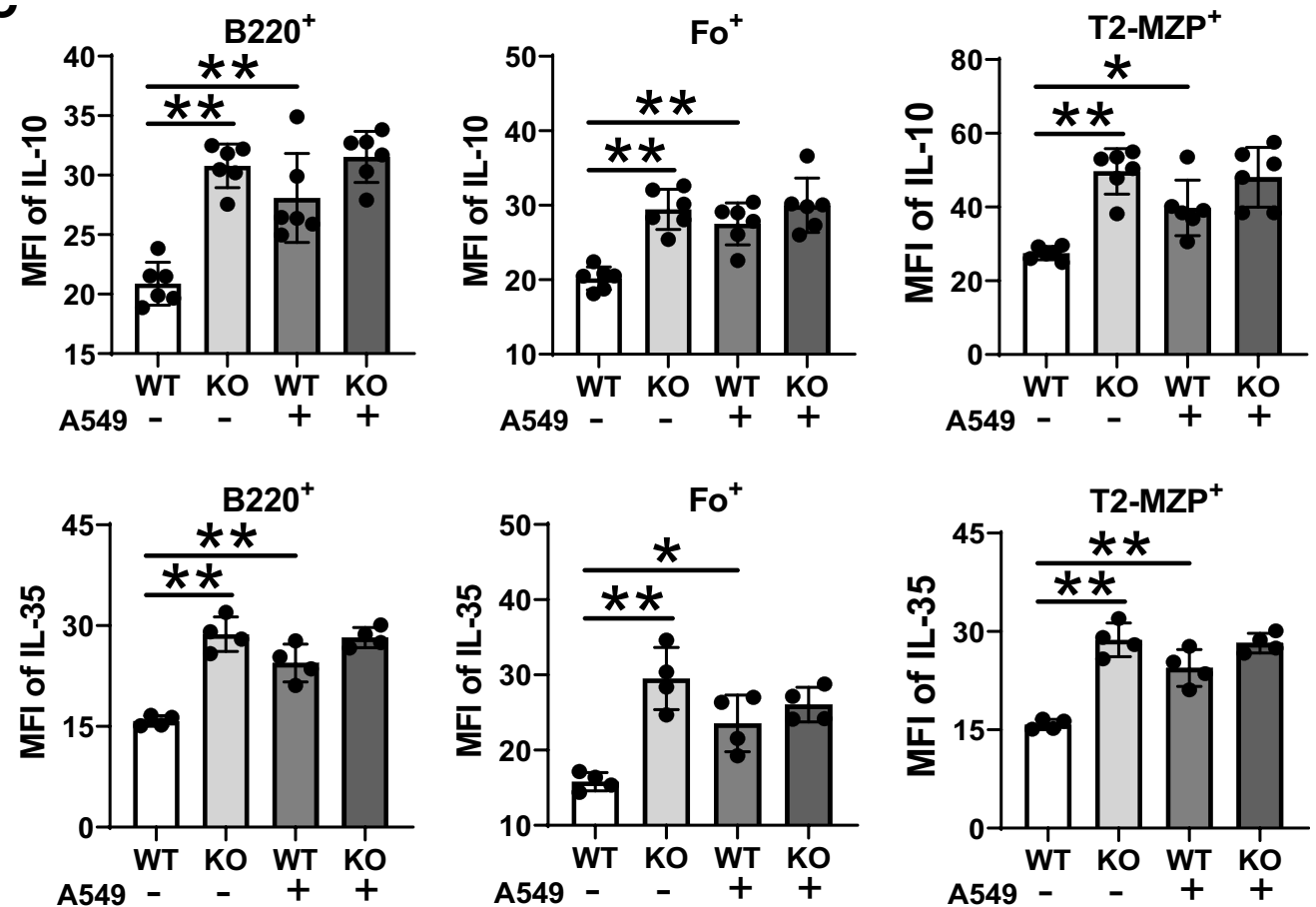

Figure 3 Increase of B-regulatory cells in the $l a l^{-/-}$lymph nodes (LNs). Lymph node cells were isolated from wild-type (WT) and lal ${ }^{-/-}$mice with or without lung A549 cancer cell transplantation and analyzed by flow cytometry using antibodies against CD23, B220, and IgM. A: Profiling and gating strategy of B-cell subset follicle (Fo) and transitional two-marginal zone precursor (T2-MZP) cells in lymph nodes from WT and lal ${ }^{-1-}$ [knockout (K0)] mice. B: The percentages of $\mathrm{FO}^{+}$and $\mathrm{T2}-\mathrm{MZP}^{+}$cells in lymph node cells and the T2-MZP/Fo ratio. The experiments were independently repeated six times. C: The mean fluorescent intensity (MFI) of IL-10 and IL-35 in $\mathrm{B}_{2} 20^{+}, \mathrm{Fo}^{+}$, and T2-MZP ${ }^{+}$cells. The gating strategy is shown in Supplemental Figure S3A. The experiments were independently repeated six times for IL-10 and four times for IL-35. Data are given as means \pm SD (B and C). ${ }^{*} P<0.05,{ }^{* *} P<0.01$.

of activated $\left(\mathrm{CD}^{+} 9^{+}\right) \mathrm{CD} 4^{+}$and $\mathrm{CD} 8^{+}$cells, and there was no statistical difference in activated $\left(\mathrm{CD} 69^{+}\right) \mathrm{B} 220^{+}$cells in the $\mathrm{lal}^{-/-}$lymph nodes after A549 injection (Figure 2C). These results indicate that activation of lymphocytes was impaire in the $\mathrm{lal}^{-1-}$ lymph nodes in response to A549 cancer cell injection. In addition, Ki-67 staining was used for the measurement of T-cell proliferation in response to tumor antigen. A549 injection increased percentages of $\mathrm{CD} 4^{+} \mathrm{Ki}-67^{+}$ 
A
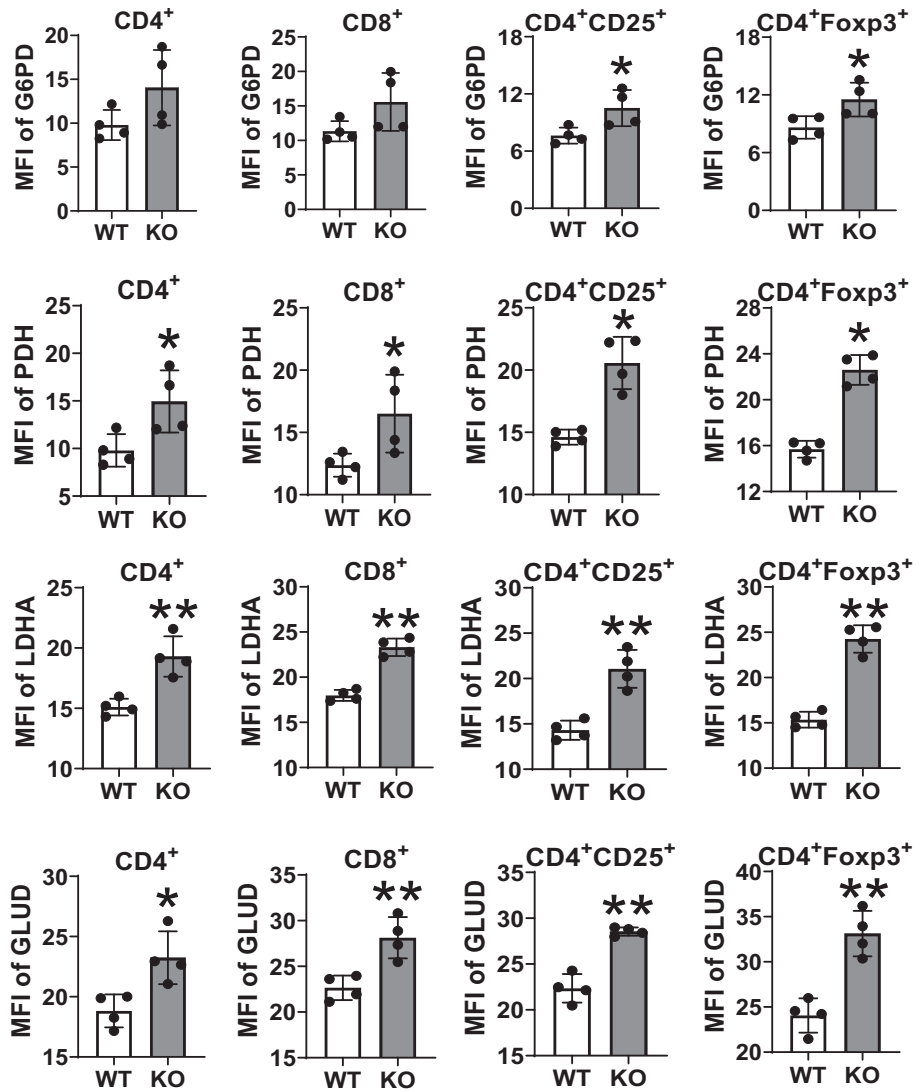

B
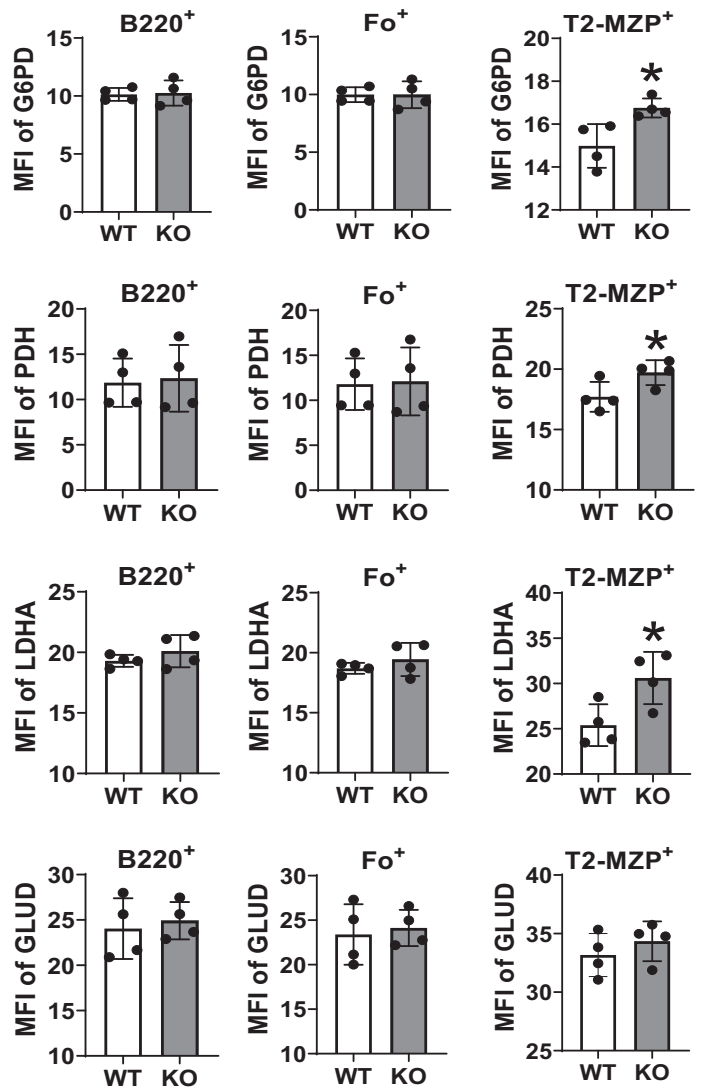

Figure 4 Increased expression of glucose and amino acid metabolic enzymes in T- and B-regulatory cells of the lal ${ }^{-/-}$lymph nodes. Lymph node cells were isolated from wild-type (WT) and $l a l^{-/}$mice and analyzed by flow cytometry. A: The mean fluorescent intensity (MFI) of glucose-6-phosphate dehydrogenase (G6PD), pyruvate dehydrogenase (PDH), lactate dehydrogenase $\mathrm{A}(\mathrm{LDHA})$, and glutamate dehydrogenase (GLUD) in $\mathrm{CD} 4^{+}, \mathrm{CD}^{+}, \mathrm{CD}^{+} \mathrm{CD}^{+} 5^{+}$, and $\mathrm{CD} 4^{+} \mathrm{FOXP3}{ }^{+}$ cells. B: The MFI of G6PD, PDH, LDHA, and GLUD in $\mathrm{B}_{220^{+}}$, follicle $(\mathrm{Fo})^{+}$, and transitional two-marginal zone precursor (T2-MZP) ${ }^{+}$cells. The gating strategy is shown in Supplemental Figure S4A. The experiments were independently repeated four times. Data are given as means \pm SD $(\mathbf{A}$ and $\mathbf{B})$. ${ }^{*} P<0.05,{ }^{* *} P<0.01$. K0, knockout.

and $\mathrm{CD} 8^{+} \mathrm{Ki}-67^{+}$cells, with more $\mathrm{CD} 4^{+} \mathrm{Ki}-67^{+} \mathrm{T}$ cells in wild-type lymph nodes than in $l a l^{-/-}$lymph nodes, suggesting that T-cell proliferation was increased in response to A549 cancer cell injection, especially in wild-type lymph nodes (Figure 2D and Supplemental Figure S2C).

Tregs critically regulate antitumor immunity and are crucial for the maintenance of cancer tolerance. The $l a l^{-/-}$ lymph nodes showed significantly higher percentages of $\mathrm{CD} 4{ }^{+} \mathrm{CD} 25^{+}$and $\mathrm{CD} 4{ }^{+} \mathrm{FOXP}_{3}{ }^{+}$Tregs than those of the wild-type lymph nodes in mice not injected with A549 (Figure 2E and Supplemental Figure S2D). A549 injection increased percentages of both $\mathrm{CD} 4{ }^{+} \mathrm{CD} 25^{+}$and $\mathrm{CD} 4{ }^{+} \mathrm{FOXP} 3^{+}$Tregs in the wild-type lymph nodes, and did not change $\mathrm{CD} 4{ }^{+} \mathrm{CD} 25^{+}$Tregs and decreased $\mathrm{CD}^{+}{ }^{+} \mathrm{FOXP}^{+}{ }^{+}$Tregs in $l a l^{-/-}$lymph nodes (Figure $2 \mathrm{E}$ and Supplemental Figure S2D), probably due to intrinsic defects of T-cell response and homeostasis.

\section{Bregs Are Expanded in the lal $^{-/-}$Lymph Nodes}

Bregs preferentially accumulate in the tumor-draining lymph nodes and promote tumor growth. ${ }^{14}$ Populations of follicle and transitional two-marginal zone precursor (T2-MZP) cells were defined within the B220 population of wild-type and the $l a l^{-1-}$ lymph nodes (Figure 3A), as previously reported. ${ }^{14}$ The percentages of follicle and T2-MZP in the $\mathrm{lal}^{-1-}$ lymph nodes were all significantly higher than those in the wild-type lymph nodes (Figure 3B). After A549 injection, the increased percentage of the T2-MZP Breg subpopulation in the wild-type lymph nodes was still lower than that in the $\mathrm{lal}^{-1-}$ lymph nodes. The overall T2-MZP/follicle ratio, an indicator of the Breg activity, was significantly higher in the $l a l^{-/-}$lymph nodes compared with that in the wild-type lymph nodes, regardless of A549 injection status (Figure 3B). Concomitantly, much higher mean fluorescence intensity and percentages of IL-10- and IL-35-positive B220 and T2-MZP cells were observed in the $l a l^{-1-}$ lymph nodes than those in the wild-type lymph nodes of A549-uninjected mice (Figure 3C and Supplemental Figure S3). A549 injection increased IL-10 and IL-35 levels in B220 and T2-MZP Bregs in the wild-type lymph nodes, and remained relatively unchanged in the $\mathrm{lal}^{-1-}$ lymph nodes (Figure 3C and Supplemental Figure S3). 
A

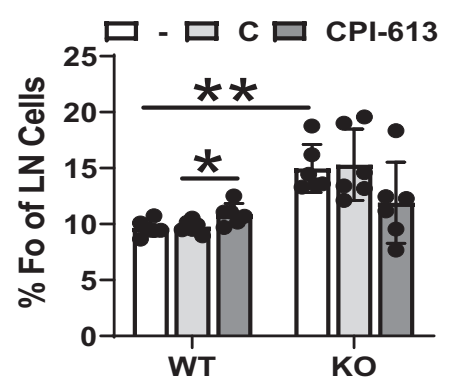

B

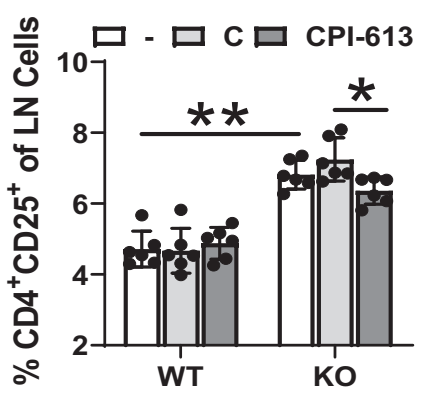

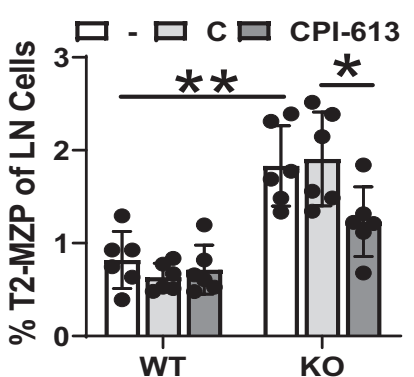

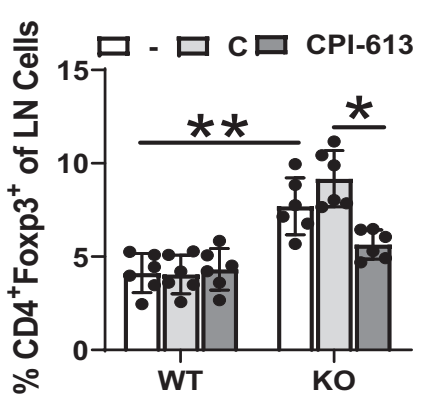

C
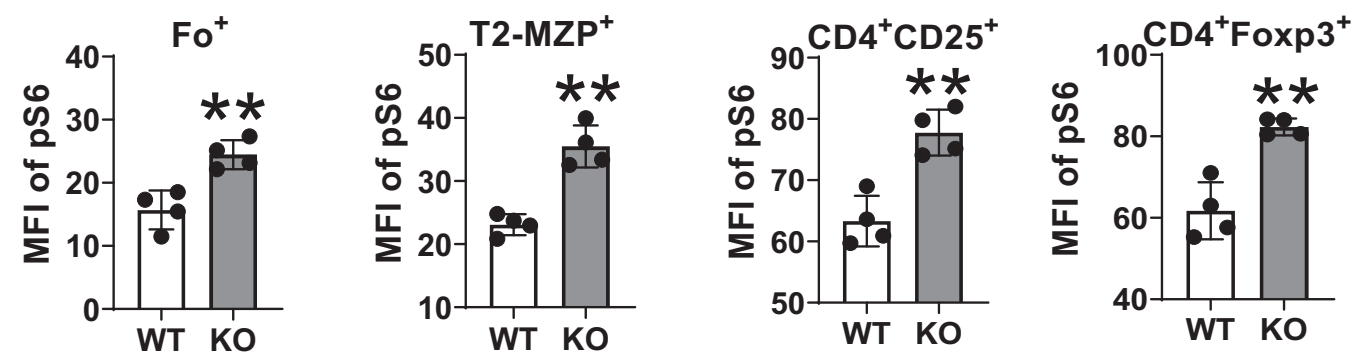

D
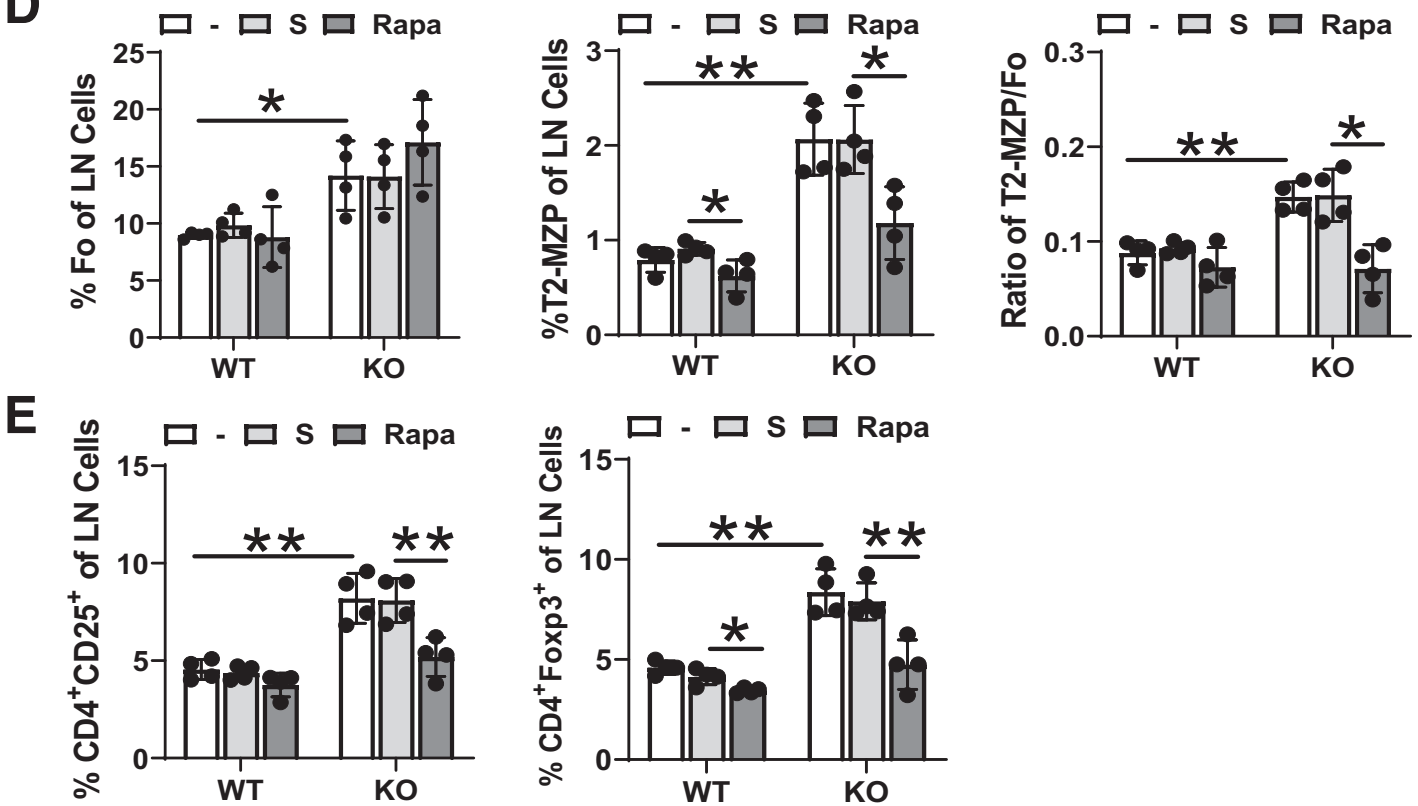

Figure 5 Blocking pyruvate dehydrogenase or mammalian target of rapamycin (mTOR) pathway reduced T- and B-regulatory cells (Tregs and Bregs, respectively) of the lymph nodes (LNs). Lymph node cells were isolated from CPI-613 or rapamycin (Rapa) treated or untreated wild-type (WT) and lal ${ }^{-/-}$mice and analyzed by flow cytometry. A: The percentages of follicle (Fo) and transitional two-marginal zone precursor (T2-MZP) Bregs and the T2-MZP/Fo ratio in the lymph node cells of wild-type and lal $^{-/}{ }^{-}$mice that were treated with CPI- $613(5 \mathrm{mg} / \mathrm{kg})$. B: The percentages of Tregs in the lymph node cells of wild-type and $\mathrm{lal}^{-1-}$ mice that were treated with CPI-613 (5 mg/kg). C: Expression of mTOR downstream pS6 in Bregs and Tregs. The gating strategy is shown in Supplemental Figure S5. D: The percentages of Fo and T2-MZP Bregs and the T2-MZP/Fo ratio in the lymph node cells of rapamycin-treated or untreated wildtype and $l a l^{-1-}$ mice. E: The percentages of Tregs in the lymph node cells of rapamycin-treated or untreated wild-type and lal ${ }^{-1-}$ mice. The experiments were independently repeated six times $(\mathbf{A}$ and $\mathbf{B})$ or four times $(\mathbf{C}-\mathbf{E})$. Data are expressed as means $\pm \mathrm{SD}(\mathbf{A}-\mathbf{E})$. ${ }^{*} P<0.05,{ }^{*} P<0.01$. -, untreated; $\mathbf{C}$, solvent control; KO, knockout; MFI, mean fluorescent intensity; S, solvent. 
A

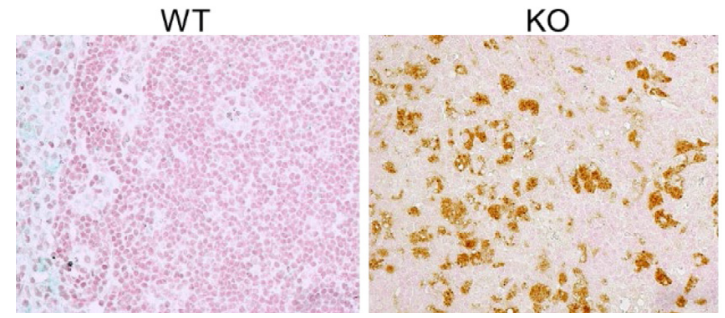

B
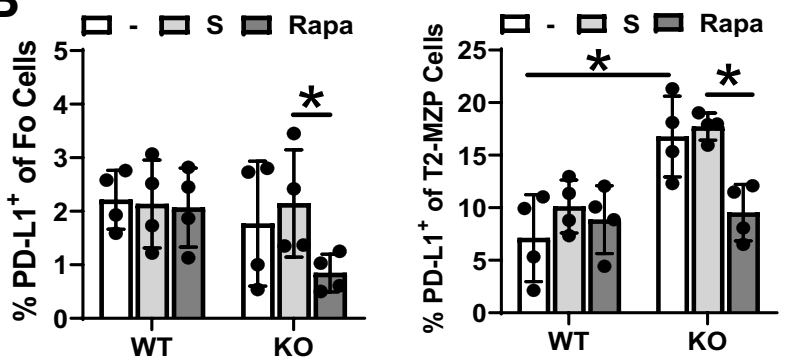

C
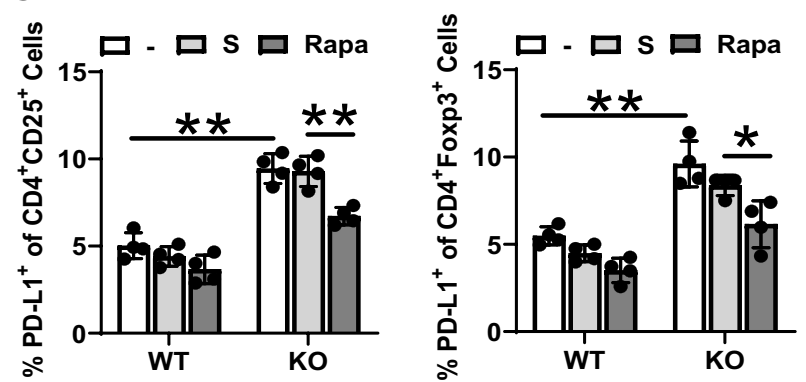

D

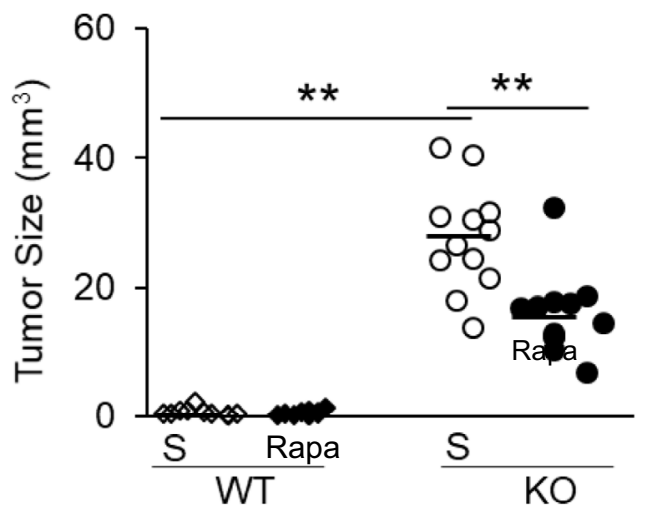

Figure 6 Blocking mammalian target of rapamycin reduced PD-L1 expression in T- and B-regulatory cells (Tregs and Bregs, respectively) of the lymph nodes and decreased human lung A549 cancer cell growth in $\mathrm{lal}^{-1-}$ mice. A: Immunohistochemical staining of PD-L1 in lymph nodes of wild-type (WT) and $\mathrm{lal}^{-{ }^{-}}$[knockout (KO)] mice. B and C: PD-L1 expression in follicle (Fo) and transitional two-marginal zone precursor (T2-MZP) Bregs (B) and Tregs (C) of the lymph node cells from rapamycin (Rapa)-treated or untreated WT and $\mathrm{lal}^{-/-}$mice. D: Human lung A549 cancer cells were transplanted into WT or $\mathrm{lal}^{-1-}$ (KO) mice that were pretreated with rapamycin, as described in Materials and Methods. The tumor volume at 10 days after A549 transplantation is shown. Other time points are shown in Supplemental Figure S6A. The experiments were independently repeated 4 times (B and $\mathbf{C}$ ) or 12 times (D). Data are expressed as means \pm SD (B-D). ${ }^{*} P<0.05,{ }^{*} P<<0.01$. Original magnification, $\times 400$ (A). - , untreated; $S$, solvent.
Metabolic Changes in Tregs and Bregs of the $\mathrm{lal}^{-1-}$ Lymph Nodes

In fat catabolism, triglycerides are hydrolyzed to break into fatty acids and glycerol by LAL. Fatty acids are further broken down through a process known as fatty acid $\beta$-oxidation, which results in acetyl-CoA, which can be used in the tricarboxylic acid cycle in mitochondria. ${ }^{18}$ Therefore, fatty acid metabolism supports both the biosynthetic and bioenergetic requirements of cell proliferation and survival. In the absence of the regular supply of fatty acids during LAL deficiency, it is important to determine if the energy consumption switches toward the glucose and amino acid metabolic pathways. Indeed, in most cases, glucose metabolic enzymes, including PDH (controlling the entrance from glycolysis to tricarboxylic acid cycle), glucose-6phosphate dehydrogenase (controlling the pentose phosphate pathway), and lactate dehydrogenase (controlling anaerobic glycolysis), were all increased in both mean fluorescence intensity and percentage of positive cells in $\mathrm{lal}^{-/-}$Tregs (Figure 4A and Supplemental Figure S4, A and B) and Bregs (T2-MZP) (Figure 4B and Supplemental Figure S4, A and C). Among amino acid pathways, glutamate dehydrogenase, which controls the glutamate conversion to $\alpha$-ketoglutarate in the tricarboxylic acid cycle, was also increased in $\mathrm{lal}^{-/-}$Tregs (Figure 4A and Supplemental Figure S4, A and B). These observations suggest a metabolic shift from fatty acids toward glucose and amino acid utilization in Tregs and Bregs of the $\mathrm{lal}^{-/-}$lymph nodes. Injection of CPI-613, a PDH inhibitor, into mice decreased both T2-MZP Bregs and $\mathrm{CD} 4{ }^{+} \mathrm{CD} 25^{+} / \mathrm{CD} 4^{+} \mathrm{FOXP} 3^{+}$ Tregs of the $l a l^{-/}$lymph nodes (Figure 5, A and B).

mTOR is a major signal integrator for metabolic regulation of nutrients, energy, and stress. ${ }^{19-22}$ The lysosomal surface hosts molecular machinery for mTOR activation. ${ }^{22,23}$ Activation of this pathway promotes influx of glucose and amino acids into the cells. ${ }^{24,25}$ Up-regulation of metabolic enzymes in glucose and glutamine pathways implicates that the mTOR pathway serves as a critical mechanism to control Treg and Breg homeostasis in the $\mathrm{lal}^{-1-}$ lymph nodes. The increase of phosphorylated S6, a major mTOR effector, was observed in Tregs and Bregs of the $\mathrm{lal}^{-/-}$lymph nodes (Figure 5C and Supplemental Figure S5). Furthermore, injection of mTOR inhibitor rapamycin into mice significantly reduced the T2MZP Breg population in both wild-type and $\mathrm{lal}^{-/-}$lymph nodes, which resulted in reduced T2-MZP/follicle ratio (Figure 5D). Rapamycin treatment also reduced the $\mathrm{CD} 4{ }^{+} \mathrm{CD} 25^{+}$and $\mathrm{CD} 4{ }^{+} \mathrm{FOXP} 3^{+}$Treg cell percentages in the $\mathrm{lal}^{-/-}$lymph nodes (Figure 5E).

Immunohistochemical expression of PD-L1 was observed in the lymph nodes of $l a l^{-/-}$mice (Figure 6A). Furthermore, flow cytometry analyses showed significant increase of PD-L1 in Bregs and Tregs in the $l a l^{-/-}$lymph nodes than those in the wild-type lymph nodes. PD-L1 expression was reduced in T2-MZP Bregs and in $\mathrm{CD}^{+}{ }^{+} \mathrm{CD} 25^{+}$and $\mathrm{CD}^{+} \mathrm{FOXP}^{+}$Tregs of the $\mathrm{lal}^{-1-}$ 
A
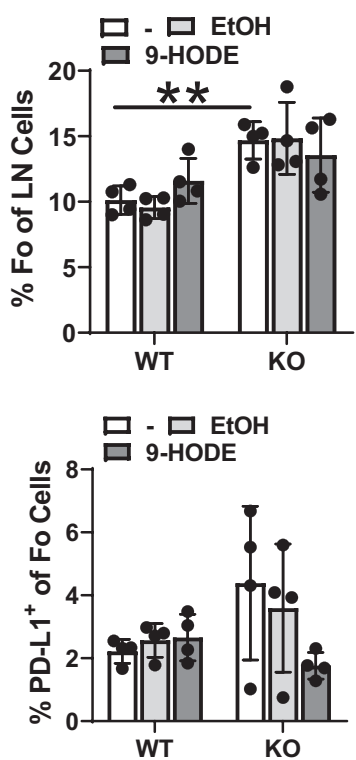

B
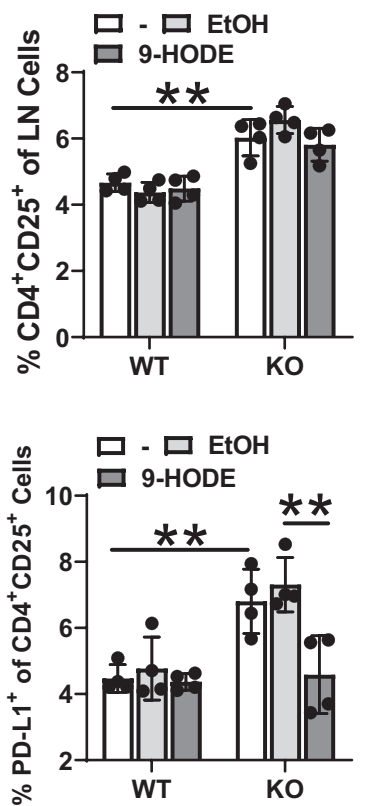
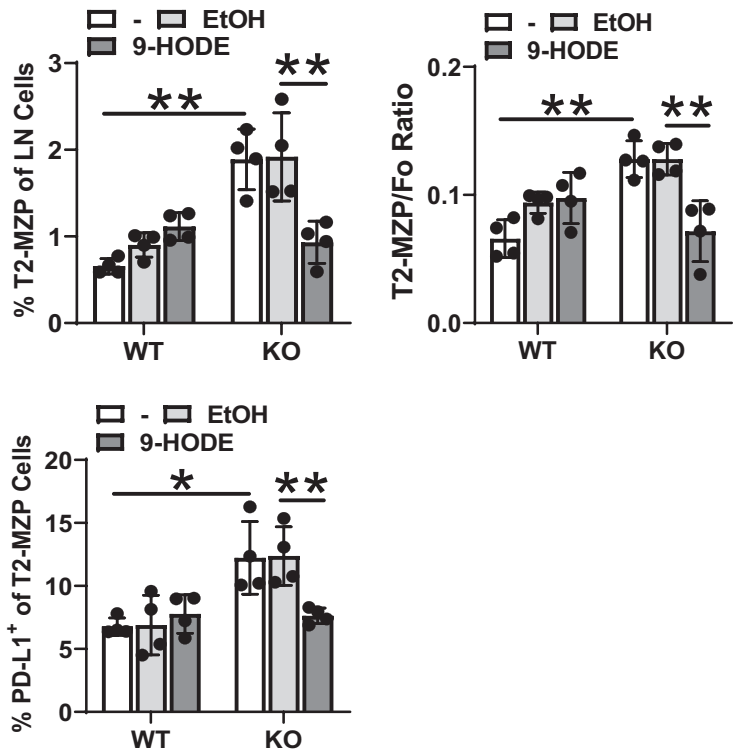

C
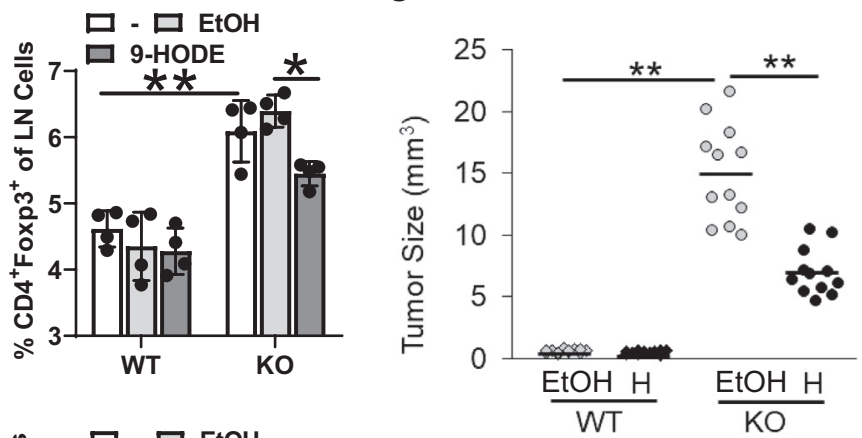

Figure 7 Treatment of 9-HODE (H) reduces T and B-regulatory cells (Tregs and Bregs, respectively) of the lymph nodes (LNs) and human lung A549 cancer cell growth in $\mathrm{lal}^{-{ }^{-}-}$mice. Lymph node cells were isolated from 9-HODE treated or untreated wild-type (WT) and lal ${ }^{-{ }^{-}}$[knockout (KO)] mice and analyzed by flow cytometry. A: The percentages of follicle (Fo) and transitional two-marginal zone precursor (T2-MZP) Bregs, the T2-MZP/Fo ratio, and PD-L1 expression in Fo and T2-MZP Bregs. B: The percentages of Tregs and PD-L1 expression in Tregs. C: Human lung A549 cancer cells were transplanted into wild-type or lal ${ }^{-1-}$ mice that were pretreated with 9-HODE, as described in Materials and Methods. The tumor volume at 10 days after A549 transplantation is shown. 0ther time points are shown in Supplemental Figure S6B. The experiments were independently repeated 4 times (A and B) or 12 times (C). Data are expressed as means \pm SD $(\mathbf{A}-\mathbf{C}) .{ }^{*} P<0.05,{ }^{*} P<0.01$. -, untreated; Et0H, ethanol.

lymph nodes after rapamycin treatment (Figure 6, B and C). As a consequence, rapamycin injection reduced human lung A549 cancer cell growth in xenotransplanted $\mathrm{lal}^{-/-}$ mice (Figure 6D and Supplemental Figure S6A). Taken together, these results demonstrated that the mTORcontrolled metabolic pathway plays a pivotal role in Treg and Breg homeostasis, which contributes to tumorpromoting functions in the lymph nodes of $l a l^{-/-}$mice.
Reactivation of PPAR $\gamma$ Reduces Tregs and Bregs of the lal $^{-/-}$Lymph Nodes and Xenotransplanted Human

\section{Cancer Cell Growth}

LAL hydrolyzes cholesteryl esters and triglycerides in lysosomes to generate free fatty acids and cholesterol. ${ }^{26,27}$ Derivatives of free fatty acid metabolites serve as hormonal ligands for nuclear receptors (eg, PPAR $\gamma$ ), which 

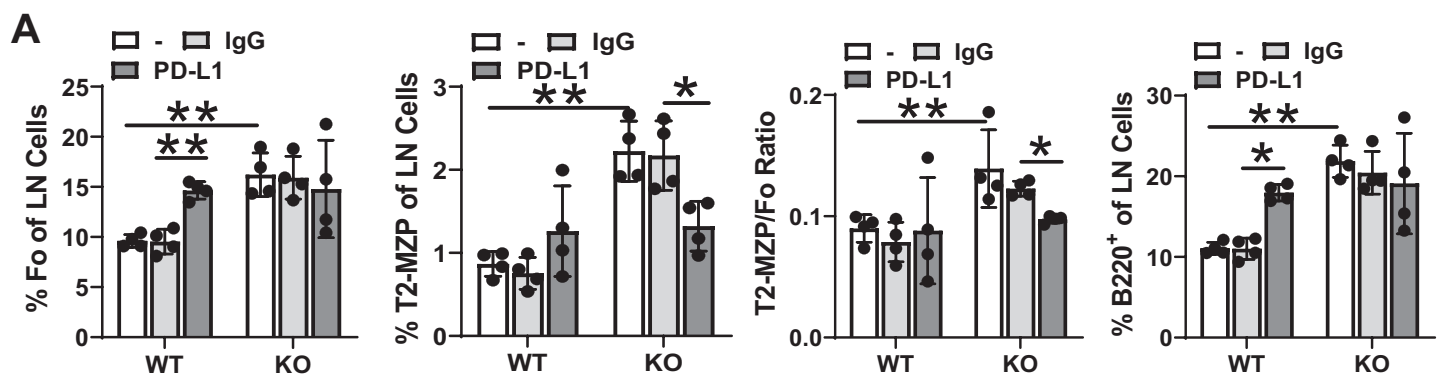

B
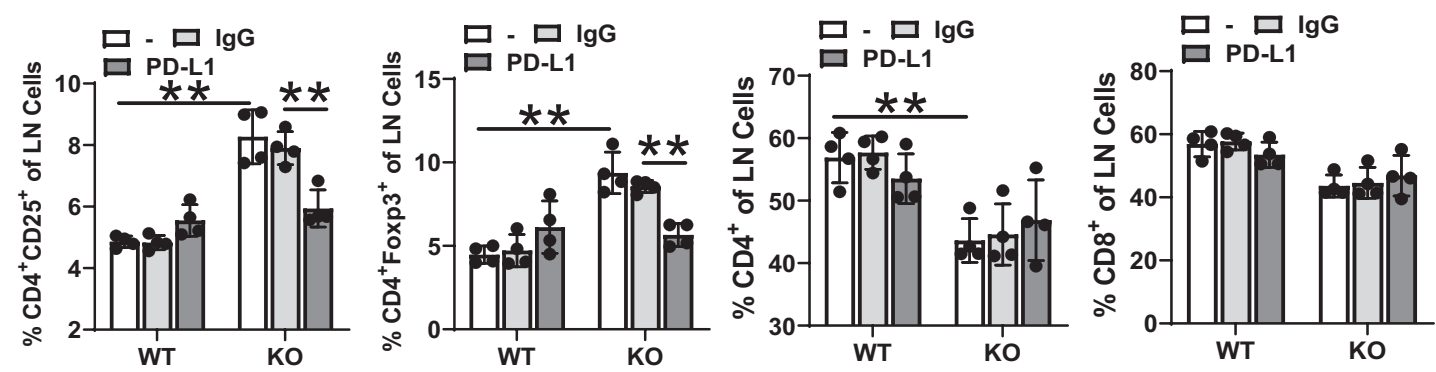

C

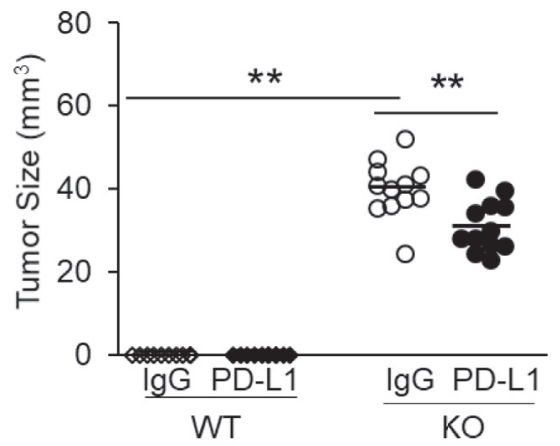

Figure 8 Blocking PD-L1 reduced T- and B-regulatory cells (Tregs and Bregs, respectively) of the lymph nodes (LNs) and decreased human A549 cancer cell growth in $\mathrm{lal}^{-/-}$mice. Lymph node cells were isolated from PD-L1 antibody-treated wild-type (WT) and lal $^{-/-}$ [knockout (KO)] mice and analyzed by flow cytometry. A: The percentages of follicle (Fo) and transitional two-marginal zone precursor (T2-MZP) Bregs and the T2-MZP/Fo ratio. B: The percentages of Tregs. C: Human lung A549 cancer cells were transplanted into wild-type or $\mathrm{lal}^{-/-}$mice that were pretreated with PD-L1 antibody, as described in Materials and Methods. The tumor volume at 10 days after A549 transplantation is shown. Other time points are shown in Supplemental Figure S6C. The experiments were independently repeated 4 times (A and $\mathbf{B}$ ) or 12 times (C). Data are expressed as means $\pm \mathrm{SD}(\mathbf{A}-\mathbf{C}) .{ }^{*} P<0.05,{ }^{* *} P<0.01$. - , untreated. are hormone-regulated transcription factors. When synthesis of PPAR $\gamma$ hormonal ligands is diminished by LAL deficiency, inactivation of PPAR $\gamma$ promotes elevation of Tregs and Bregs in the $l a l^{-1-}$ lymph nodes. To test this hypothesis, 9-HODE, a natural ligand for $\operatorname{PPAR} \gamma$, was reintroduced into $\mathrm{lal}^{-1-}$ mice. 9-HODE generation in cells is LAL-dependent. ${ }^{28}$ 9-HODE injection significantly reduced percentages of T2-MZP Bregs and $\mathrm{CD} 4^{+} \mathrm{Foxp}^{+}$ Tregs in the $l_{a l}{ }^{-1}$ lymph nodes (Figure 7, A and B). PD-L1 expression in T2-MZP Bregs and in $\mathrm{CD} 4{ }^{+} \mathrm{CD} 25^{+}$ and $\mathrm{CD} 4{ }^{+} \mathrm{FOXP}_{3}{ }^{+}$Tregs was also reduced after 9-HODE treatment (Figure 7, A and B). 9-HODE injection reduced human lung A549 cancer cell growth in xenotransplanted $l a l^{-/-}$mice (Figure 7C and Supplemental Figure S6B). These results demonstrate that reactivation of PPAR $\gamma$ improves immune rejection of human cancers in $\mathrm{lal}^{-/-}$ mice.
Inhibition of PD-L1 Reduces Tregs and Bregs of the $\mathrm{lal}^{-/-}$Lymph Nodes and Xenotransplanted Human Cancer Cell Growth

Because expression of PD-L1 in Bregs and Tregs was significantly higher in the $l a l^{-/-}$lymph nodes than in the wild-type lymph nodes (Figure 6, B and C), and both rapamycin and 9-HODE reduced PD-L1 expression (Figure 6, B and C, and Figure 7, A and B), it is important to identify the role of PD-L1 in Breg and Treg homeostasis. Anti-PD-L1 antibody was used to block the PD-L1 activity. Anti-PD-L1 antibody injection into mice significantly reduced T2-MZP Bregs and $\mathrm{CD} 4{ }^{+} \mathrm{CD} 25^{+} / \mathrm{CD} 4{ }^{+} \mathrm{FOXP} 3^{+}$ Tregs in the $\mathrm{lal}^{-1-}$ lymph nodes (Figure 8, A and B). Anti-PD-L1 antibody injection also reduced human lung A549 cancer cell growth in xenotransplanted $\mathrm{lal}^{-/-}$mice (Figure 8C and Supplemental Figure S6C). Therefore, 
elevated expression of PD-L1 by $\mathrm{lal}^{-/-}$Bregs and Tregs at least partially contributes to human lung A549 cancer cell growth in xenotransplanted $\mathrm{lal}^{-1-}$ mice.

\section{Discussion}

Because murine B16 melanoma and Lewis lung carcinoma cells are able to grow and metastasize in both syngeneic and allogeneic $l a l^{-1-}$ mouse models, ${ }^{9}$ we speculated that human cancer cells would also grow across species in this mouse model. The current study clearly demonstrates that the metabolic landscape shifts as a result of LAL deficiency and leads to immune evasion by human lung A549 cancer cells (Figure 1A). Therefore, lal ${ }^{-/-}$mice potentially serve as a xenograft model for human cancer cell transplantation, which provides a valuable tool for clinical and therapeutic application of human cancers.

It has been demonstrated previously that multiple organs and cells in $l a l^{-1-}$ mice participate in this tumorigenic process and contribute to weakened immune rejection. In the bone marrow, development and differentiation of hematopoietic stem cells skew toward myeloid lineage cells, especially at the stage of CD11b/Ly6G/Ly6C triple-positive MDSCs. As a result, lal $^{-1-}$ MDSC production in the blood and distal organs (thymus, spleen, lung, and liver) is significantly increased. ${ }^{7}$ $\mathrm{Lal}^{-1-}$ MDSCs directly stimulate tumor cell proliferation, progression, and metastasis both in vitro and in vivo. ${ }^{9} \mathrm{Lal}^{-/-}$ MDSCs suppress T-cell differentiation and function, ${ }^{8,10}$ which jeopardizes the antitumor immunity. Myeloidspecific expression of the human version of LAL reverses the T-cell suppressive function of $\mathrm{lal}^{-/-}$MDSCs. ${ }^{10,29} \mathrm{Lal}^{-/-}$ MDSCs also affect angiogenesis by regulating EC proliferation and various other functions to influence penetration of tumor cells and MDSCs across the EC barrier. ${ }^{30}$

In contrast, LAL deficiency down-regulates development and differentiation of lymphocytes in multiple organs. In addition to suppression by MDSCs that have infiltrated into these organs, the intrinsic defect is a critical factor of T-lymphocyte shortage. LAL deficiency impairs T-cell development in the thymus at the DN3 $\left(\mathrm{CD} 44^{-} \mathrm{CD} 25^{+}\right)$to DN4 $\left(\mathrm{CD} 44^{-} \mathrm{CD} 25^{-}\right)$transition. $^{6}$ The peripheral $l a l^{-/-}$T-cell population is reduced dramatically, due largely to increased apoptosis and decreased proliferation of $\mathrm{lal}^{-/-} \mathrm{T}$ cells. $\mathrm{Lal}^{-/-}$ $\mathrm{T}$ cells lose the ability to respond to T-cell receptor stimulation, with decreased T-cell proliferation and expression of T lymphokines. The ratio increase of $\mathrm{CD} 4{ }^{+} \mathrm{CD} 25^{+} \mathrm{FoxP}^{+}$Tregs to $\mathrm{CD}^{+}{ }^{+} \mathrm{T}$ cells is observed in $\mathrm{lal}^{-/-}$spleens. ${ }^{6}$ It has been reported that memory $\mathrm{T}$ cells rely on cell-intrinsic expression of the LAL for memory T-cell development and fate. ${ }^{31}$

In addition to the immune system, cell types in other organs also participate in tumorigenesis caused by LAL deficiency. For example, cell-specific expression of the human LAL in $\mathrm{lal}^{-1-}$ mice shows that LAL deficiency in liver hepatocytes or lung type II epithelial cells actively contributes to tumor growth and metastasis in $\mathrm{lal}^{-1-}$ mice. $^{32,33}$ In the circulatory system, ECs lining the inner layer of blood vessels function as barriers regulating tumor cell and leukocyte transmigration. The intrinsic defect of $\mathrm{lal}^{-1-}$ ECs causes altered migration and proliferation, decreased apoptosis, and impaired tube formation and angiogenesis. As a result, tumor cells and leukocytes (MDSCs and $\mathrm{T}$ cells) transmigrate more efficiently across the $l a l^{-/-} \mathrm{EC}$ barrier than the $l a l^{+/+} \mathrm{EC}$ barrier. During this process, $l_{a l}{ }^{-1-}$ ECs suppress T-cell proliferation. ${ }^{30}$

While searching for the underlying cellular mechanism of diminished immune rejection of human lung A549 cancer cells, further analyses identified abnormal homeostasis and functions of the al $^{-/-}$lymph nodes in this report. The balance between immune effector cells and immunosuppressive cells in the lymph nodes plays a crucial role in regulating tumor rejection. ${ }^{13-15}$ In the lal ${ }^{-/-}$lymph nodes, both Treg and Breg populations were significantly increased compared with those of the wild-type lymph nodes (Figures 2 and 3). Effector cytokine IFN- $\gamma$, a CD8 ${ }^{+}$T-cell function indicator, failed to respond to human lung A549 cell lysate challenge, whereas the IL-10 level, an important indicator for Treg- and Breg-mediated immunosuppression, was increased dramatically in the $l a l^{-/-}$lymph nodes (Figure $1 \mathrm{~F}$ ). Granzyme B, a $\mathrm{CD}^{+} \mathrm{T}$ cell produced killing factor of cancer cells, also failed to respond to human lung A549 cell lysate challenge in lal $^{-/-}$lymph node cells (Figure 1F).

The immunosuppressive activity of Tregs and Bregs promotes tumor growth in the tumor microenvironment. ${ }^{34}$ It has been shown that the frequency of Tregs in the tumor-draining lymph nodes, rather than that in tumors and peripheral blood, positively correlates with disease stage, ${ }^{35}$ and the expression level of $\mathrm{FOXP}^{+}$correlates with poor 5-year survival rate in stage I non-small-cell lung cancer patients. ${ }^{36}$ On the other hand, Bregs represent a population of B cells that participate in immunomodulation and in suppression of immune responses. ${ }^{37,38}$ The tumor-draining lymph nodes in cancer patients show up-regulation of Bregs. Bregs preferentially accumulate in tumor-draining lymph nodes and promote tumor growth. ${ }^{14}$ Through the production of IL-10 and IL-35, Bregs suppress type 1 helper $\mathrm{T}$ cells, type 17 helper $\mathrm{T}$ cells, and cytotoxic $\mathrm{CD} 8^{+} \mathrm{T}$ cells, and facilitate the conversion of $\mathrm{T}$ cells to Tregs $\left(\mathrm{FOXP}^{+} \mathrm{T}\right.$ cells), thus attenuating antitumor immune responses. ${ }^{39}$ Up-regulation of Bregs correlates with increased frequency of Tregs, increased progression of carcinoma, and reduced patient survival. ${ }^{40}$ In both murine and human immune systems, IL-10 production is regarded as a crucial indicator of Bregs. ${ }^{39,41-43}$ Bregs also produce PD-L1 to inhibit tumor-directed cytotoxic T-cell functions. ${ }^{44}$

To better understand how Tregs and Bregs promote tumor progression by suppressing antitumor responses, it is essential to identify the nature of the molecular components and pathways promoting the generation and proliferation of Tregs and Bregs in the lal $^{-/-}$lymph nodes. Although Tregs are defined by lineage-specific marker FOXP3, no lineagespecific marker has been conclusively identified in Bregs, which are rather reactive to the environment. ${ }^{38}$ 
There is evidence indicating that not only cancer cells go through metabolic reprograming; immune cells also have distinct metabolic characteristics that influence their functions. ${ }^{45,46}$ In this report, several molecules and pathways that mediate increase of Tregs and Bregs in the $l a l^{-1-}$ lymph nodes have been identified. First, in Bregs and Tregs of the $l a l^{-1-}$ lymph nodes, up-regulations of G6PG, PDH, lactate dehydrogenase, and glutamate dehydrogenase (Figure 4) have been observed, indicating that blocked fatty acid oxidation due to LAL deficiency may promote $\mathrm{T}$ and $\mathrm{B}$ cells to utilize alternative energy resources. This metabolic switch may play a role in the formation of Tregs and Bregs in the $\mathrm{lal}^{-1-}$ lymph nodes. Indeed, PDH inhibitor CPI-613 reduced the increased levels of Tregs and Bregs by blocking the entrance from glycolysis to the tricarboxylic acid cycle (Figure 5, A and B). The mTOR pathway is a sensor for cellular metabolic switch, which was increased in $l a l^{-/-}$ Tregs and Bregs (Figure 5C). Treatment with rapamycin, an mTOR inhibitor, also blocked elevation of Treg and Breg levels in $\mathrm{lal}^{-1-}$ lymph nodes (Figure 5, D and E), which resulted in partially restored immune rejection of human lung A549 cell growth in vivo (Figure 6D). Collectively, these data suggest that LAL-controlled lipid metabolism is potentially important to control lymph node homeostasis and anticancer functions.

In addition to serving as fuel, the LAL downstream derivatives serve as hormonal ligands for PPAR $\gamma$. Treatment with 9-HODE, a native ligand for PPAR $\gamma$, decreased the levels of Tregs and Bregs in the lymph nodes (Figure 7, A and $\mathrm{B}$ ), which restored immune rejection of human lung A549 cancer cell growth in lal ${ }^{-1-}$ mice in vivo (Figure 7C). Interestingly, PD-L1 expression was elevated in Bregs (Figure 6B) and Tregs (Figure 6C) in the $\mathrm{lal}^{-/-}$lymph nodes. Both rapamycin and 9-HODE treatments decreased PD-L1 expression in these cells (Figure 6, B and C, and Figure 7, $\mathrm{A}$ and $\mathrm{B})$. After PD-L1 antibody treatment, $l a l^{-1-}$ mice showed decreased levels of Bregs and Tregs in the $\mathrm{lal}^{-/-}$ lymph nodes (Figure 8, A and B), and restored immune rejection of human lung A549 cancer cell growth in $\mathrm{lal}^{-/}$ mice in vivo (Figure 8C). PD-L1 is commonly expressed on Tregs and Bregs in the tumor microenvironment. ${ }^{47,48}$ PD-L1 regulates the development, maintenance, and function of Tregs. ${ }^{49}$ Bregs suppress T-cell function via IL-10 and PDL1. ${ }^{50}$ These findings indicate that the LAL/PPAR $\gamma / \mathrm{mTOR}$ axis potentially controls Breg and Treg homeostasis through regulating PD-L1 in the $l a l^{-/-}$lymph nodes.

Taken together, the metabolic reprogramming caused by LAL deficiency plays diverse functions in different organs and cells to control tumorigenesis, which collectively contribute to depletion of immune rejection of human cancer cell growth in $l a l^{-/-}$mice.

\section{Acknowledgment}

We thank Erica Johnson for proofreading of the article.

\section{Supplemental Data}

Supplemental material for this article can be found at http://doi.org/10.1016/j.ajpath.2020.10.007.

\section{References}

1. Zitvogel L, Pitt JM, Daillere R, Smyth MJ, Kroemer G: Mouse models in oncoimmunology. Nat Rev Cancer 2016, 16:759-773

2. Shultz LD, Goodwin N, Ishikawa F, Hosur V, Lyons BL, Greiner DL: Human cancer growth and therapy in immunodeficient mouse models. Cold Spring Harbor Protocols 2014, 2014:694-708

3. Palucka AK, Coussens LM: The basis of oncoimmunology. Cell 2016, 164:1233-1247

4. Du H, Duanmu M, Witte D, Grabowski GA: Targeted disruption of the mouse lysosomal acid lipase gene: long-term survival with massive cholesteryl ester and triglyceride storage. Hum Mol Genet 1998, 7:1347-1354

5. Yan C, Zhao T, Du H: Lysosomal acid lipase in cancer. Oncoscience $2015,2: 727-728$

6. Qu P, Du H, Wilkes DS, Yan C: Critical roles of lysosomal acid lipase in T cell development and function. Am J Pathol 2009, 174:944-956

7. Qu P, Shelley WC, Yoder MC, Wu L, Du H, Yan C: Critical roles of lysosomal acid lipase in myelopoiesis. Am J Pathol 2010, 176:2394-2404

8. Ding X, Du H, Yoder MC, Yan C: Critical role of the mTOR pathway in development and function of myeloid-derived suppressor cells in lal(-/-) mice. Am J Pathol 2014, 184:397-408

9. Zhao T, Du H, Ding X, Walls K, Yan C: Activation of mTOR pathway in myeloid-derived suppressor cells stimulates cancer cell proliferation and metastasis in lal(-/-) mice. Oncogene 2015, 34:1938-1948

10. Qu P, Yan C, Blum JS, Kapur R, Du H: Myeloid-specific expression of human lysosomal acid lipase corrects malformation and malfunction of myeloid-derived suppressor cells in lal-/- mice. J Immunol 2011, 187: 3854-3866

11. Du H, Cameron TL, Garger SJ, Pogue GP, Hamm LA, White E, Hanley KM, Grabowski GA: Wolman disease/cholesteryl ester storage disease: efficacy of plant-produced human lysosomal acid lipase in mice. J Lipid Res 2008, 49:1646-1657

12. Gatza E, Okada CY: Tumor cell lysate-pulsed dendritic cells are more effective than TCR Id protein vaccines for active immunotherapy of T cell lymphoma. J Immunol 2002, 169:5227-5235

13. Cochran AJ, Huang RR, Lee J, Itakura E, Leong SP, Essner R: Tumour-induced immune modulation of sentinel lymph nodes. Nat Rev Immunol 2006, 6:659-670

14. Ganti SN, Albershardt TC, Iritani BM, Ruddell A: Regulatory B cells preferentially accumulate in tumor-draining lymph nodes and promote tumor growth. Scientific Reports 2015, 5:12255

15. Swartz MA, Lund AW: Lymphatic and interstitial flow in the tumour microenvironment: linking mechanobiology with immunity. Nat Rev Cancer 2012, 12:210-219

16. Dunn GP, Koebel CM, Schreiber RD: Interferons, immunity and cancer immunoediting. Nat Rev Immunol 2006, 6:836-848

17. Parker BS, Rautela J, Hertzog PJ: Antitumour actions of interferons: implications for cancer therapy. Nat Rev Cancer 2016, $16: 131-144$

18. Boroughs LK, DeBerardinis RJ: Metabolic pathways promoting cancer cell survival and growth. Nat Cell Biol 2015, 17: $351-359$

19. Heitman J, Movva NR, Hall MN: Targets for cell cycle arrest by the immunosuppressant rapamycin in yeast. Science 1991, 253: 905-909

20. Sabatini DM, Erdjument-Bromage H, Lui M, Tempst P, Snyder SH: RAFT1: a mammalian protein that binds to FKBP12 in a rapamycindependent fashion and is homologous to yeast TORs. Cell 1994, 78: 35-43 
21. Brown EJ, Albers MW, Shin TB, Ichikawa K, Keith CT, Lane WS, Schreiber SL: A mammalian protein targeted by G1-arresting rapamycin-receptor complex. Nature 1994, 369:756-758

22. Zoncu R, Efeyan A, Sabatini DM: mTOR: from growth signal integration to cancer, diabetes and ageing. Nat Rev Mol Cell Biol 2011, 12:21-35

23. Korolchuk VI, Saiki S, Lichtenberg M, Siddiqi FH, Roberts EA, Imarisio S, Jahreiss L, Sarkar S, Futter M, Menzies FM, O'Kane CJ, Deretic V, Rubinsztein DC: Lysosomal positioning coordinates cellular nutrient responses. Nat Cell Biol 2011, 13:453-460

24. Guertin DA, Sabatini DM: Defining the role of mTOR in cancer. Cancer Cell 2007, 12:9-22

25. Recher C, Dos Santos C, Demur C, Payrastre B: mTOR, a new therapeutic target in acute myeloid leukemia. Cell Cycle 2005, 4:1540-1549

26. Yan C, Du H: Lysosomal acid lipase is critical for myeloid-derived suppressive cell differentiation, development, and homeostasis. World J Immunol 2014, 27:42-51

27. Grabowski GA, Charnas L, Du H. Lysosomal Acid Lipase Deficiencies: The Wolman Disease/Cholesteryl Ester Storage Disease Spectrum: The Online Metabolic \& Molecular Bases of Inherited Disease. Edited by Valle D, Beaudet AL, Vogelstein K, Antonarakis B, Scriver CR, Sly WS, Emeritus B, Gibson M. ed 9. New York, NY USA: McGraw-Hill Medical Publishing Division, 2012

28. Nagy L, Tontonoz P, Alvarez JG, Chen H, Evans RM: Oxidized LDL regulates macrophage gene expression through ligand activation of PPARgamma. Cell 1998, 93:229-240

29. Yan C, Lian X, Li Y, Dai Y, White A, Qin Y, Li H, Hume DA, Du H: Macrophage-specific expression of human lysosomal acid lipase corrects inflammation and pathogenic phenotypes in lal-/- mice. Am J Pathol 2006, 169:916-926

30. Zhao T, Ding X, Du H, Yan C: Myeloid-derived suppressor cells are involved in lysosomal acid lipase deficiency-induced endothelial cell dysfunctions. J Immunol 2014, 193:1942-1953

31. O'Sullivan D, van der Windt GJ, Huang SC, Curtis JD, Chang CH, Buck MD, Qiu J, Smith AM, Lam WY, DiPlato LM, Hsu FF, Birnbaum MJ, Pearce EJ, Pearce EL: Memory CD8(+) T cells use cell-intrinsic lipolysis to support the metabolic programming necessary for development. Immunity 2014, 41:75-88

32. Zhao T, Ding X, Du H, Yan C: Lung epithelial cell-specific expression of human lysosomal acid lipase ameliorates lung inflammation and tumor metastasis in Lipa(-/-) mice. Am J Pathol 2016, 186:2183-2192

33. Du H, Zhao T, Ding X, Yan C: Hepatocyte-specific expression of human lysosome acid lipase corrects liver inflammation and tumor metastasis in lal(-/-) mice. Am J Pathol 2015, 185:2379-2389

34. Turk MJ, Guevara-Patino JA, Rizzuto GA, Engelhorn ME, Sakaguchi S, Houghton AN: Concomitant tumor immunity to a poorly immunogenic melanoma is prevented by regulatory $\mathrm{T}$ cells. $\mathrm{J}$ Exp Med 2004, 200:771-782
35. Deng L, Zhang H, Luan Y, Zhang J, Xing Q, Dong S, Wu X, Liu M, Wang S: Accumulation of foxp3 $+\mathrm{T}$ regulatory cells in draining lymph nodes correlates with disease progression and immune suppression in colorectal cancer patients. Clin Cancer Res 2010, 16: $4105-4112$

36. Hanagiri T, Fukumoto M, Koyanagi Y, Furutani Y, Tanaka F: Regulatory T-cells and micrometastasis in lymph nodes of stage I NSCLC. Anticancer Res 2014, 34:7185-7190

37. Balkwill F, Montfort A, Capasso M: B regulatory cells in cancer. Trends Immunol 2013, 34:169-173

38. Rosser EC, Mauri C: Regulatory B cells: origin, phenotype, and function. Immunity 2015, 42:607-612

39. Olkhanud PB, Damdinsuren B, Bodogai M, Gress RE, Sen R, Wejksza K, Malchinkhuu E, Wersto RP, Biragyn A: Tumor-evoked regulatory $\mathrm{B}$ cells promote breast cancer metastasis by converting resting CD4(+) T cells to T-regulatory cells. Cancer Res 2011, 71:3505-3515

40. Liu J, Wang H, Yu Q, Zheng S, Jiang Y, Liu Y, Yuan G, Qiu L: Aberrant frequency of IL-10-producing B cells and its association with Treg and MDSC cells in non small cell lung carcinoma patients. Hum Immunol 2016, 77:84-89

41. Sarvaria A, Madrigal JA, Saudemont A: B cell regulation in cancer and anti-tumor immunity. Cell Mol Immunol 2017, 14:662-674

42. Allman D, Pillai S: Peripheral B cell subsets. Curr Opin Immunol 2008, 20:149-157

43. Kurosaki T: B-lymphocyte biology. Immunol Rev 2010, 237:5-9

44. Shalapour S, Font-Burgada J, Di Caro G, Zhong Z, Sanchez-Lopez E, Dhar D, Willimsky G, Ammirante M, Strasner A, Hansel DE, Jamieson C, Kane CJ, Klatte T, Birner P, Kenner L, Karin M: Immunosuppressive plasma cells impede T-cell-dependent immunogenic chemotherapy. Nature 2015, 521:94-98

45. Biswas SK: Metabolic reprogramming of immune cells in cancer progression. Immunity 2015, 43:435-449

46. Norata GD, Caligiuri G, Chavakis T, Matarese G, Netea MG, Nicoletti A, O'Neill LA, Marelli-Berg FM: The cellular and molecular basis of translational immunometabolism. Immunity 2015, 43:421-434

47. Khalil DN, Smith EL, Brentjens RJ, Wolchok JD: The future of cancer treatment: immunomodulation, CARs and combination immunotherapy. Nat Rev Clin Oncol 2016, 13:273-290

48. Pardoll DM: The blockade of immune checkpoints in cancer immunotherapy. Nat Rev Cancer 2012, 12:252-264

49. Francisco LM, Salinas VH, Brown KE, Vanguri VK, Freeman GJ, Kuchroo VK, Sharpe AH: PD-L1 regulates the development, maintenance, and function of induced regulatory T cells. J Exp Med 2009, 206:3015-3029

50. Schaut RG, Lamb IM, Toepp AJ, Scott B, Mendes-Aguiar CO, Coutinho JF, Jeronimo SM, Wilson ME, Harty JT, Waldschmidt TJ, Petersen CA: Regulatory IgDhi B cells suppress $\mathrm{T}$ cell function via IL-10 and PD-L1 during progressive visceral leishmaniasis. J Immunol 2016, 196:4100-4109 